Institutional Report

\title{
ICAR-Central Arid Zone Research Institute, Jodhpur: Erosion Processes and Desertification in the Thar Desert of India
}

P C MOHARANA*, P SANTRA, D V SINGH, SURESH KUMAR, R K GOYAL, DEEPESH MACHIWAL and O P YADAV

(Received on 06 April 2016; Accepted on 25 June 2016)

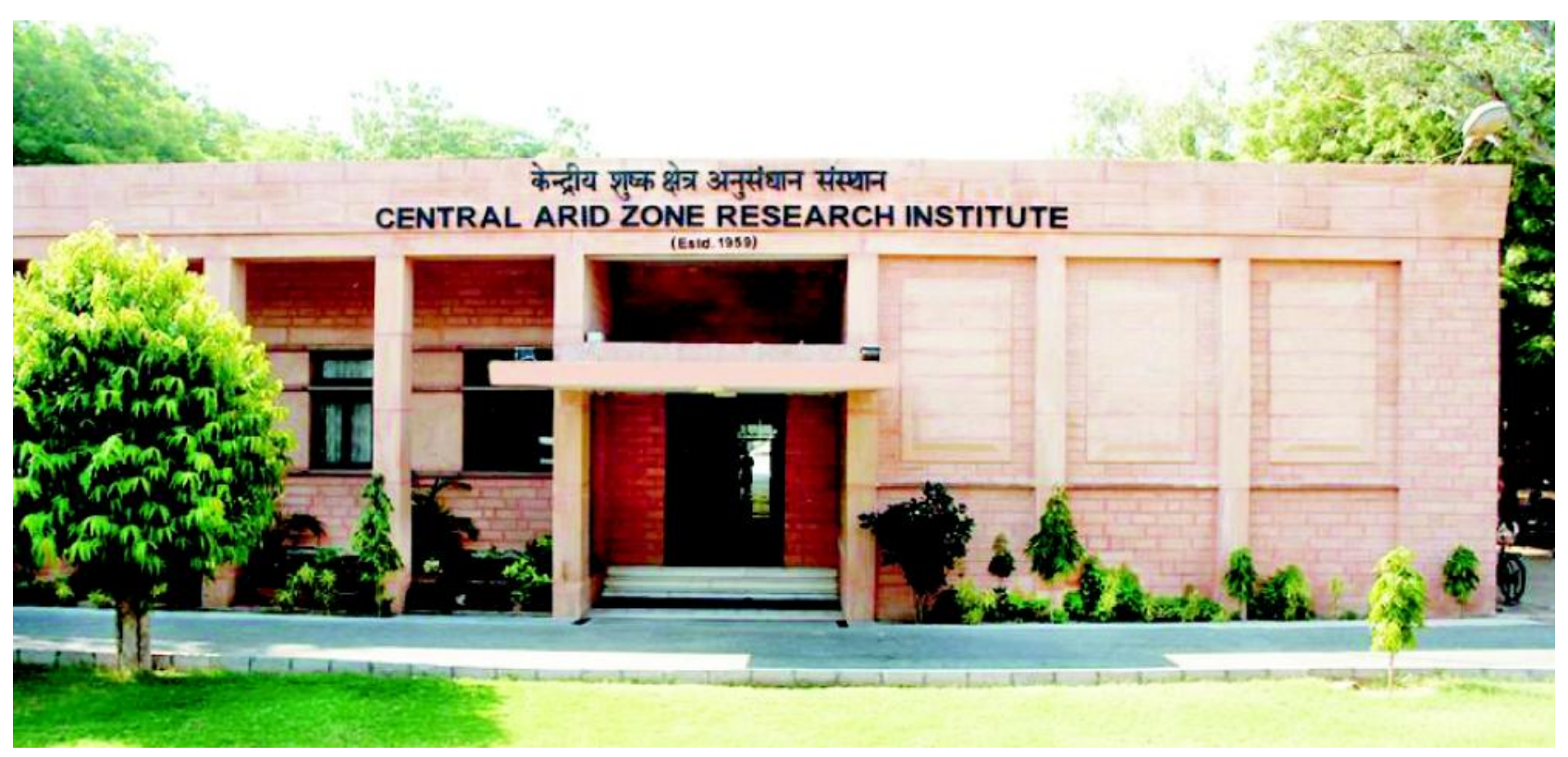

\section{Introduction}

In early and mid-twentieth century, there were speculations and apprehension that the Thar Desert is spreading towards east and it may cover large fertile areas of present day Punjab, Haryana, west Uttar Pradesh and east Rajasthan. Therefore, the Government of India established a Desert Afforestation Research Station at Jodhpur, Rajasthan in 1952 mainly to focus on sand dune stabilization and shelterbelt plantations to reduce wind erosion. In 1957, it was reorganized as Desert Afforestation and Soil Conservation Station. Just after two years (in 1959), it was restructured as the Central Arid Zone Research Institute (CAZRI).
At present, CAZRI has five Regional Research Stations (RRSs) at Bikaner, Jaisalmer and Pali in Rajasthan, at Kukma-Bhuj in Gujarat and at Leh in Jammu and Kashmir. The RRS at Leh was established recently in August, 2012 to address the problems of cold arid agriculture. The institute has three Krishi Vigyan Kendras (KVKs) located at Jodhpur, Pali and Kukma-Bhuj; and five field areas for range management studies. It hosts an All India Network Project on Vertebrate Pest Management with its centre in many institutes and State Agricultural Universities located in different agro-ecological regions of the country. At present the mandates of the institute are:

\footnotetext{
*Authorfor Correspondence: E-mail:pcmoharana45@gmail.com
} 
- To undertake basic and applied research on sustainable farming systems in the arid ecosystem

- To act as repository of information on the state of natural resources and desertification processes

- Developing livestock-based farming systems and range management practices for the chronically drought-affected areas

- Generating and transferring location-specific technologies.

Since its inception, CAZRI has been following the integrated resources management approach. It has carried out research on assessment, monitoring and management of natural resources of Indian arid zone; development of integrated farming systems; improvement of crops, grasses, shrubs, trees and fruits; livestock production and management; use of alternate energy resources, etc. The institute has evolved strategies for combating drought and desertification. It has developed several need-based, cost effective technologies like shelterbelt plantation, wind erosion control, sand dune stabilization, watershed development, rehabilitation of wastelands, arid land farming systems, alternate land use strategies, range management, pest management, post-harvest technologies and value addition, farm implements, etc. Several solar energy devices like solar cooker, solar water heater, animal feed solar cooker, solar dryers, solar candle making device, PV duster, PV winnower, PV based water pumping system for irrigation etc. have been developed. The institute remains in direct touch with the farmers through its extension wing and three KVKs. The institute works in close liaison with national and international institutes and stakeholders working for the development of arid agro-ecosystem.

This report highlights the recent work pertaining to the theme 'Natural resources monitoring, desertification and its control' carried out by the institute. Since, CAZRI addresses the issues related to arid regions of the country, we begin with a short appraisal of the arid ecosystem, especially the Thar Desert, in India.

\section{The Indian Arid Zone, Thar Desert Terrain and Environment}

The arid region of India is spread in 38.7 million hectare ( $\mathrm{m} \mathrm{ha}$ ) area out of which $31.7 \mathrm{~m}$ ha is under hot arid zone and $7 \mathrm{~m}$ ha under cold arid zone. The hot arid region occupies major part of north-western India, covering western part of Rajasthan (19.6 m ha, 61.9\%), north-western Gujarat (6.22 m ha, 19.6\%), Punjab and Haryana (2.75 m ha, $8.6 \%$ ), Karnataka (2.7\%), Maharashtra (0.4\%) and Andhra Pradesh $(6.8 \%)$. Arid western Rajasthan falls under two agroclimatic regions; western Dry region and TransGangetic plain region. The western dry region which lies to the west of Aravalli hills, comprises 12 districts of the state of Rajasthan being distributed over four agro-climatic zones (Fig. 1). Jaisalmer, Barmer, Bikaner, Churu and Jodhpur in Arid western plain zone (133073.6 sq. km), Sri-Ganganager and Hanumangarh (Rajasthan NW canal irrigated plain, 20556.6 sq. km), Nagaur, Jhunjhunun and Sikar (Transitional plain of Inland drainage, 31329.3 sq. $\mathrm{km}$ ) and Pali and Jalor (Transitional plain of Luni basin, 22951.1 sq. km) are the districts. Area wise, Jaisalmer is the biggest district (38401 sq. $\mathrm{km}$ area) while Jhunjhunun is the smallest (5928 sq. km). The Thar, or the Great Indian Sand Desert, located within this region is a distinct, but integral part of the arid lands of western India that runs through the states of Punjab, Haryana, Rajasthan and Gujarat. The eastern limit of this zone can be marked along the calculated moisture availability index (also called the aridity index) of -66.6, which roughly passes through the foothill zone of the degraded, NNE to SSW-trending Aravalli mountain ranges. The Thar Desert terrain is characterized by dominance of aeolian (in $>80 \%$ area) and ephemeral fluvial landforms. Sand dunes are the major aeolian landforms occurring in about $48 \%$ area of western Rajasthan.

The physiography/micro-climatic variations have contributed to the development of a variety of soils derived from the alluvial and aeolian parent material with pedogenic characteristics. Hydrologically, river Luni forms the only organised drainage system. Surface water resources are limited due to low and scanty rainfall and poor water yielding efficiency of sandy terrain. Besides storage tanks, other common systems for surface water are nadis (village ponds) and khadins (runoff harvesting systems). Vegetation constitutes to be primary source of life-support 


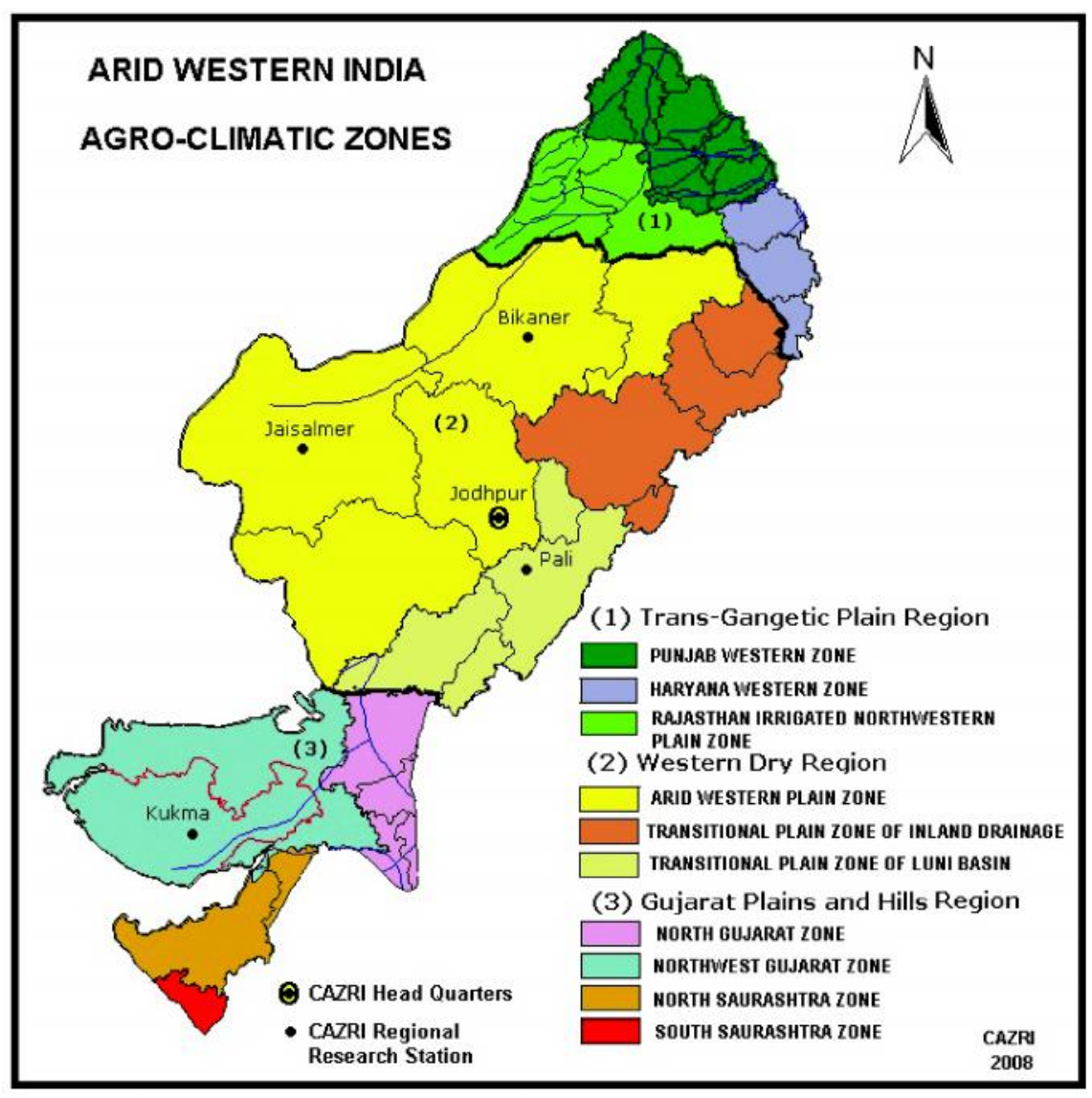

Fig. 1: Agroclimatic sub-divison of NW arid zone of India

because of dependency by animal husbandry. The northern desert thorn forest, northern Acacia scrub forest, northern Euphorbia scrub and inland dune scrub are the recognised forest types in this region.

Despite limitations of an arid environment, there is an increasing trend in the human and livestock population in the region. Between 1961 and 2011 census, human population has increased by $>250 \%$ while between 1956 and 2012 census, the animal population has increased by about $125.2 \%$. Irrespective of frequent droughts, the region has a dominant agricultural economy. The land use statistics for $2005-06$ by CAZRI shows about $61.15 \%$ area in arid western Rajasthan is utilized for cultivation which includes $51.19 \%$ as net sown area, $9.96 \%$ as double cropped area and $12.97 \%$ as net irrigated area. $29.4 \%$ area is under wastelands. An estimate of changes between 1982-83 and 2005-06 indicated an increase in net-irrigated (128\%), and double cropped area $(70 \%)$ whereas a decline of culturable waste area by $7.70 \%$. An analysis of production and income 2007-08 showed, in all the four agro-climatic zones in western Rajasthan, returns from agricultural sector contribute $26-43 \%$ of the total income, the mining 1.6$1.8 \%$, while other sectors like service, business and allied activities contribute to $56-73 \%$ of the income (CAZRI VISION 2030). In agricultural sector, income from cropping provides $59-71 \%$ of the total agricultural income while livestock provides $28-42 \%$ in all agroclimatic zone of Rajasthan.

\section{Climate and its Variability}

The key characteristic of arid regions is low precipitation compared to high atmospheric water demand. The hot arid region of India is no exception where annual rainfall is $100-500 \mathrm{~mm}$ and potential evapotranspiration (atmos-pheric water demand) is 1400-2000 mm. Most of the arid regions of the earth occur between $15^{\circ}$ and $30^{\circ}$ latitude belt in both the hemispheres, also known as mid-latitude subsidence 
zone. The moisture laden air rising from the equatorial region, sheds most of its moisture in equatorial forest region and starts descending towards the mid-latitudes. The air heats in its descent and become extremely dry. Thus, dry air often dominates in the mid-latitude arid areas. Cold arid region of Jammu \& Kashmir and Himachal Pradesh as well as some pockets of arid regions in peninsular India are mainly due to the rain shadow effect of mountains.

Rainy season is quite distinct in Indian arid zone. The precipitation is mainly received during south-west monsoon season (June-September). The monsoon reaches the Thar Desert by $1^{\text {st }}$ week July and the entire arid zone is covered by mid-July. The withdrawal of monsoon also starts from the extreme end of hot arid zone (Jaisalmer district) by September beginning. Thus, the monsoon season is effectively of 2.5 to 3 months compared to four months in most of the India. Only a few active monsoon spells bring rains in this region resulting in wide inter and intraseasonal variations in rainfall amount. Two meteorological subdivisions namely, West Rajasthan and Saurashtra \& Kutch cover most of the hot arid zone of northwest India. The annual rainfall, based on 1901-2010 rainfall data, in Western Rajasthan and Saurashtra \& Kutch met-subdivisions is 291 and 501 $\mathrm{mm}$, respectively. Most of the annual rainfall i.e. about $88 \%$ in West Rajasthan and $94 \%$ in Saurashtra \& Kutch is received during the southwest monsoon season. Though the rainfall amount is relatively high in Saurashtra \& Kutch, the coefficient of variation (CV) of monsoon season (43\%) and annual (41\%) rainfall is high compared to West Rajasthan where the $\mathrm{CV}$ of monsoon and annual rainfall is 40 and $38 \%$ respectively. The high annual and seasonal (monsoon) rainfall variability in the two met subdivisions is evident from Fig. 2.

High rainfall variability results in frequent droughts in these low rainfall areas. The intensity (rainfall deficit) and duration of droughts vary from year to year and parts of the drought affected region. Early season droughts due to late onset, terminal droughts due to early withdrawal and mid-season droughts due to monsoon breaks are very common. Attri and Tyagi (2010) reported that West Rajasthan met-subdivision faced maximum (34) droughts followed by Saurashtra \& Kutch (31) during 18752009 period (Fig. 3). The number of droughts in other met subdivisions receiving up to $1000 \mathrm{~mm}$ rainfall is also given in this figure for comparison. Gujarat region, which is adjacent to Saurashtra \& Kutch, faced 28 droughts. Similarly, the frequency of severe droughts was also high in Saurashtra \& Kutch (15), West Rajasthan (12) and Gujarat region (11). At district or smaller scale, one or other pocket in arid zone faces drought almost every year as the temporal distribution of rainfall is also highly variable during the season. Floods are relatively less common in arid zone and are limited in area coverage because of light textured soils. However, flash floods sometimes do occur in small areas due to high intensity rains.

There was increasing trend in annual as well as monsoon rainfall in both West Rajasthan and Saurashtra \& Kutch met-subdivisions from 1901 to 2010. However, the trend was statistically significant
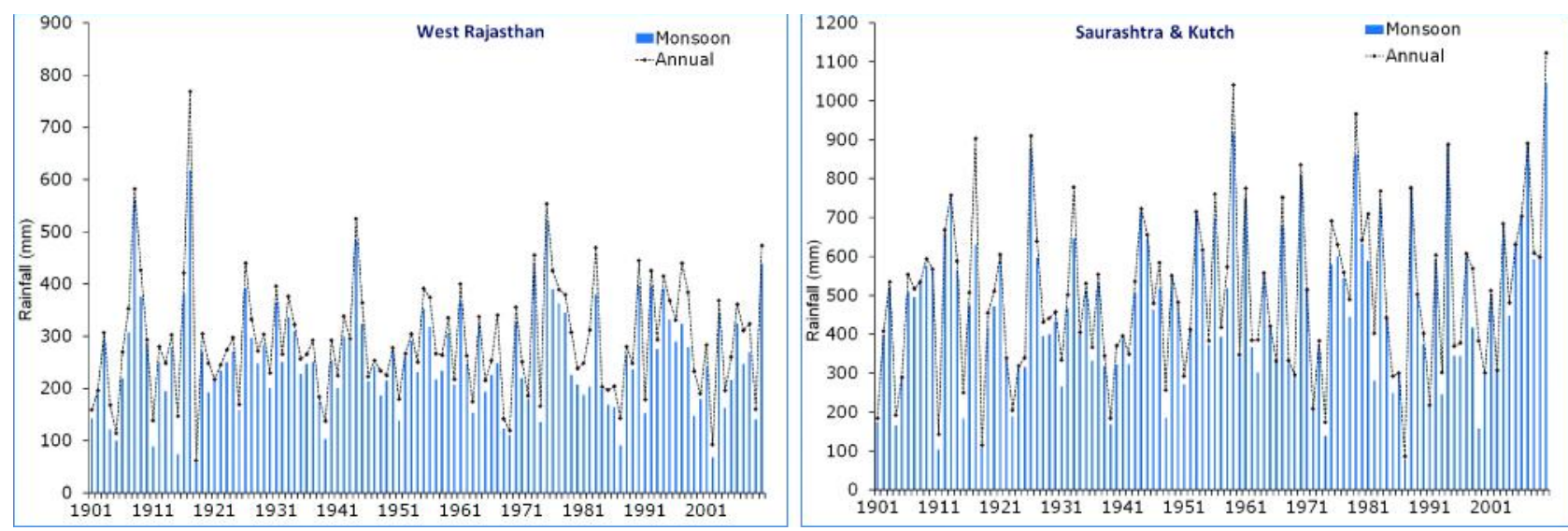

Fig. 2: Annual and monsoon rainfall in West Rajasthan and Saurashtra \& Kutch met-subdivisions during 1901-2010 (source: IMD met subdivision data series) 


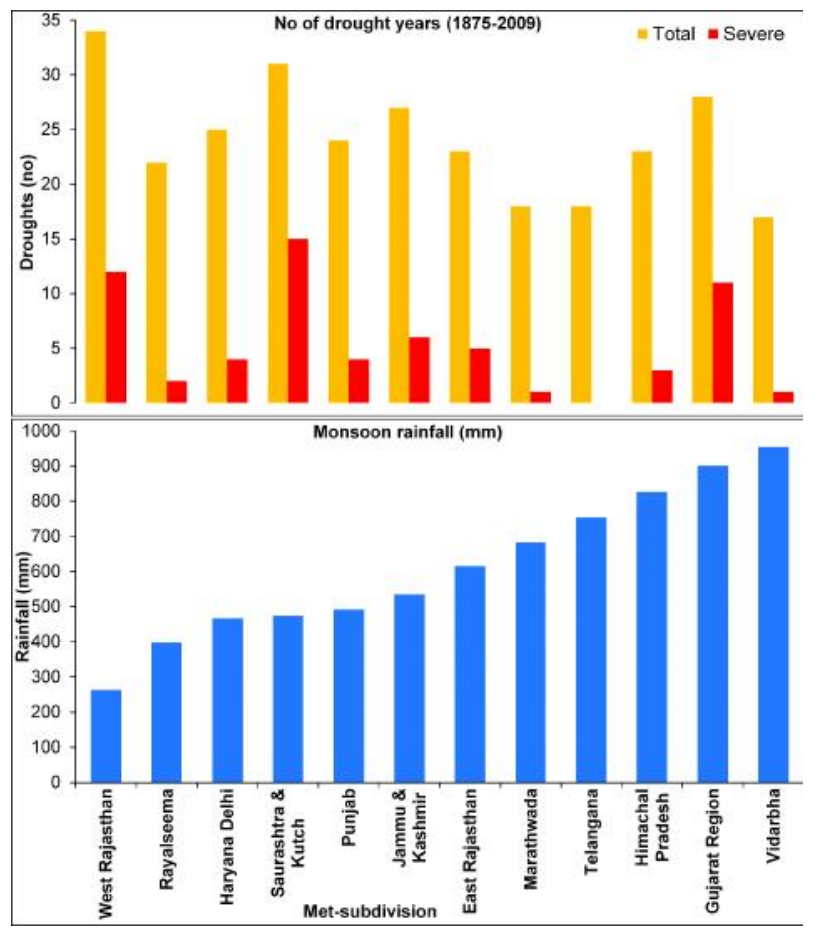

Fig. 3: Normal rainfall ( $\mathrm{mm}$ ) and number of total as well as severe drought years during 1875-2009 in selected met sub-divisions (adapted from Attri and Tyagi, 2010)

for Saurashtra \& Kutch subdivision and that too only during recent period (1981-2010) for both annual (9.4 $\left.\mathrm{mm} \mathrm{y}^{-1}\right)$ and monsoon $\left(10.1 \mathrm{~mm} \mathrm{y}^{-1}\right)$ rainfall. But, it does not imply that the trend will continue.

Since cloud cover is low during most of the year, solar radiation is abundant. In arid Rajasthan, average annual solar radiation is about $22 \mathrm{MJ} \mathrm{m}^{2} \mathrm{~d}^{-1}$ and the value ranges from $15-18 \mathrm{MJ} \mathrm{m}^{2} \mathrm{~d}^{-1}$ in winter and 2326.5 $\mathrm{MJ} \mathrm{m}^{2} \mathrm{~d}^{-1}$ in summer. Even during monsoon season, the solar radiation remains about 22-26.5 MJ $\mathrm{m}^{2} \mathrm{~d}^{-1}$. Solar radiation in drier regions (Jaisalmer and Barmer) is relatively more $\left(22.3 \mathrm{MJ} \mathrm{m}^{2} \mathrm{~d}^{-1}\right)$ than irrigated belt of Hanumangarh district $\left(20 \mathrm{MJ} \mathrm{m}^{2}\right.$ $\left.\mathrm{d}^{-1}\right)$.

The diurnal, seasonal and annual temperature range is high owing to the geographical location of the hot arid zone, sandy terrain, sparse vegetation and low soil and atmospheric moisture content. In summer season, the temperature may rise up to $50^{\circ} \mathrm{C}$, while in winter $-5.7^{\circ} \mathrm{C}$ temperature has been recorded. During winter season, the mean monthly maximum temperature ranges from $22^{\circ} \mathrm{C}$ to $29^{\circ} \mathrm{C}$ and minimum temperature from 4 to $14^{\circ} \mathrm{C}$. May is the hottest month with mean maximum temperature of $40-42^{\circ} \mathrm{C}$. The temperature declines by $3-5^{\circ} \mathrm{C}$ during monsoon season but again increases slightly during September-October with the withdrawal of monsoon.

The general wind direction follows typical monsoon wind pattern. The wind direction is normally southwest during summer and rainy season, and northeast during winter season. The wind speed remains quite low (3-4 kmph) during winter and high (9-12 kmph) during summer. Strong winds of 15 to 18 $\mathrm{kmph}$ are often observed during June and the wind speed may reach 60 to $80 \mathrm{kmph}$ during severe dust storms. During 1971-2010 period, wind speed has declined significantly, particularly during summer months (Fig. 4). The decline was more pronounced up to mid-1990s. A recent study (Vautard et al. 2010) found that winds are slowing in northern hemisphere. Such decline in wind speed was attributed mainly to changing patterns of atmospheric circulation, increased vegetation due to afforestation a changing landscape management practices and increase in urban density.

\section{Understanding the Thar Desert Terrain through Systematic Geomorphological Mapping}

Geomorphological investigation of the Thar Desert is one of the initial and leading research fields included in the Natural Resources and Environment (then called the Basic Resources Survey) Division at CAZRI since

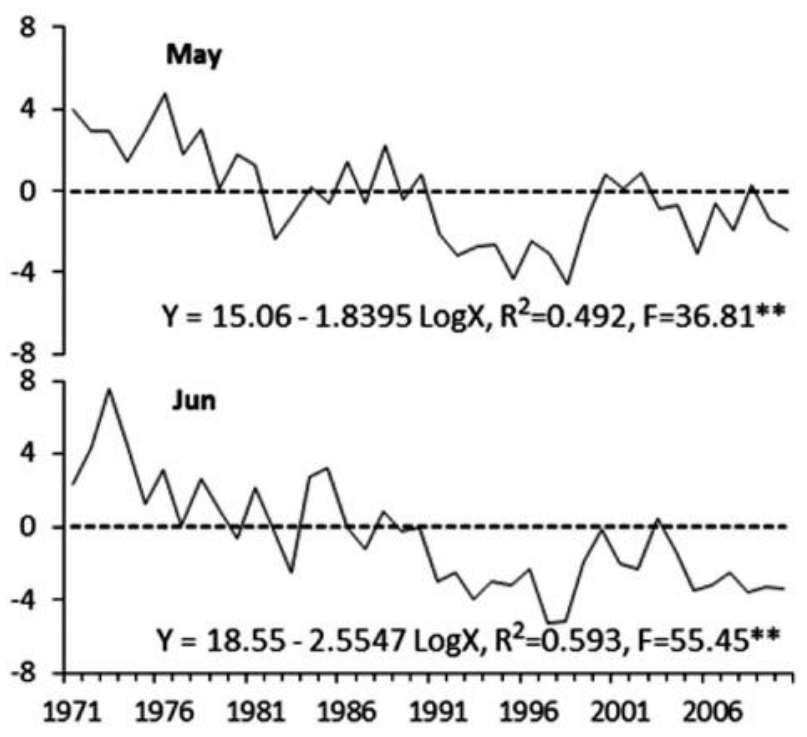

Fig. 4: Wind speed (kmph) anomaly in May and June at Jodhpur during 1971-2010 
1959. The major contributions can be systematically put under; (1) Geomorphic provinces and landforms of Thar, (2) Paleo-channels and buried streams of the Thar Desert, (3) Quantitative geomorphology of arid drainage basins, (4) Measuring wind erosivity and soil erodibility, (5) Sand dunes and their evolution in the Thar, (6) Deciphering past climates from sand dunes, (7) Evolution of inland saline lakes (Ranns) in Thar, (8) Quantitative measurement of arid fluvial processes and (9) Geomorphological and Lineament mapping of Rajasthan. Besides, institute contributed effectively in the inter-disciplinary research projects and special surveys on various aspects like; desertification in the arid regions of India, earthquakes and surface deformities of Bhuj earthquake (2001), flash floods in Luni basin (1979, 2003-04) and Barmer district (2007), severe droughts of 2002 and 2004 in western Rajasthan, genesis of salinity and waterlogging (2013-16) in IGNP canal command area and soil fertility mapping. Now, as Institute has established a new research station at Leh-Ladakh in 2012, the institute will undertake geomorphological assessment of cold arid terrain.

\section{Geomorphological mapping for western Rajasthan}

Earlier, during 1985, CAZRI had prepared a system of landform classification and mapping at 1:50000 scale that could be easily understood and used by soil scientists, plant ecologists, hydrologists, land use specialists, agricultural scientists, etc. It was based partly on the classification system developed by the Commonwealth Scientific and Industrial Research Organization (CSIRO) of Australia. The methodology, then, included the interpretation of large-scale aerial photographs, field data, laboratory analysis of sediment samples, and interpretation of large-scale topographical sheets. During 2012-2015, under a National Level Mapping project of ISRO's (Indian Space Research Organization) NRC (Natural Resources Census) programme and with technical collaboration of GSI (Geological Survey of India, western region), CAZRI contributed to preparing a geomorphological map of arid western Rajasthan using a recently developed classification system at 1:50,000 scale. The mapping involved digital interpretation of the false colour composite (FCC) of images of 200506 from Indian Remote Sensing (IRS) Satellite, LISSIII, followed by field verification of the mapped units and analysis of sediments. It generated information on the origin, processes and landform units. The mapping (Fig. 5) showed that aeolian landforms are most dominant in the area ( $79 \%$ of the total area), but actual area covered by sand dunes is about $48 \%$. Based on the origin, six types of landforms have been identified; structural, denudational, fluvial, aeolian, fluvio-marine and anthropogenic. A brief description of the results are presented below.

Landforms of structural origin account for only $2.4 \%$ area of western Rajasthan, while those of denudational origin occupy $5.1 \%$ area. The major forms are hills and valleys, dykes and ridges, pediments and pediplains. However, there is marked variations in morphology and origin. In Jaisalmer district, the hills are low and are scattered, in contrast, Barmer and Jalor districts have a few clusters of inselbergs and domes. Hamadas, the rocky structural plains, occur in Jaisalmer district. Isolated sand stone hills in Jodhpur and Nagaur districts occur as mesas and buttes while those occurring at Agolai, Korna, Gotan, Pundlu, Bilara are of rhyolite and limestone hills. Exposed fluvial landforms cover $13.3 \%$ area of western Rajasthan, the maximum area of these landforms is in Pali district (30.3\%). The major palaeochannels and abandoned channels cover 1420 $\mathrm{km}^{2}$ area $(0.7 \%)$. Younger alluvial plains cover only $2.1 \%$ area along the $462.5 \mathrm{~km}$ long Luni River and its major tributaries of western Rajasthan with very high relevance for agricultural uses.

Aeolian landforms cover $78.9 \%$ area of western Rajasthan. Sand dunes are the major aeolian features, further categorised and mapped as barchan, longitudinal, transverse, parabolic, dune complex and dissected dune complex (where the dune slope has numerous gullies). Playas or saline depressions (also known as inland rann) were mapped under sandy terrain at Sambhar, Didwana, Tal Chhapar, Pachpadra, Thob, Bap and Lunkaransar and amidst rocky terrains at Lawan, Pokaran, Dediya, Mitha Rann, Kanodwala Rann and Kharariwala Rann. Desert pavements, covering $3.3 \%$ area, occur mainly along a discontinuous belt in Phalodi-Bap-Pokaran-BhojkaBasanpir-Sankra- Kolayat in the districts of Barmer, Jaisalmer, Jodhpur and Bikaner.

Landforms of anthropogenic origin are manifestations of impact of human activities; levelling of sand dunes through mechanical methods, for 


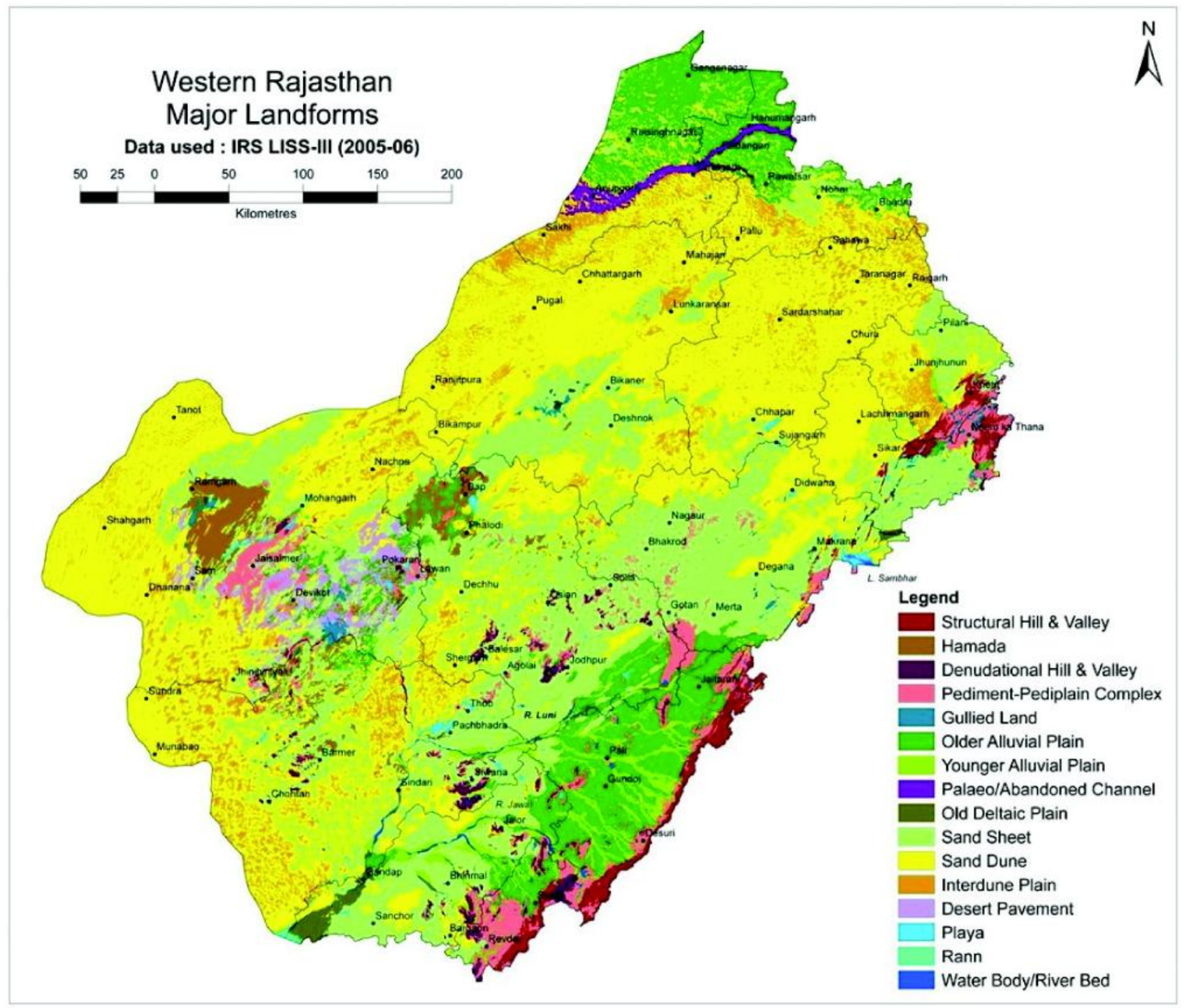

Fig. 5: Landform map of western Rajasthan (Source: Moharana et al., 2013)

cropping, mainly in the northern part; mining of salts and chemicals in salt pans in $118 \mathrm{~km}^{2}$ area, mining of sandstone, limestone, marble, gypsum, clays, lignite in $176 \mathrm{~km}^{2}$, have not only altered the local drainage system in some areas, but have also created large depressions.

\section{Water Resource, its Availability and Demand}

\section{Surface Water Resources}

The Indian hot arid region is known for very scarce water resources, a large part of the rainwater being lost as evapotranspiration. Western Rajasthan has been divided into three broad hydrological zones.
Table 1: Surface water resources (mcm) in arid Rajasthan

\begin{tabular}{lrrrr}
\hline District & Zone-I & Zone -II & Zone-III & $\begin{array}{r}\text { Total } \\
(\mathrm{mcm})\end{array}$ \\
\hline Sri Ganganagar* & 6.49 & 11.19 & - & 17.68 \\
Bikaner & 7.14 & 26.16 & - & 33.3 \\
Churu & - & 22.82 & - & 22.82 \\
Jhunjhunun & - & 8.04 & 96 & 104.04 \\
Sikar & - & 10.48 & 96 & 106.48 \\
Jaisalmer & 5.03 & 38.38 & - & 43.41 \\
Jodhpur & - & 20.66 & - & 20.66 \\
Nagaur & - & 53.18 & - & 53.18 \\
Pali & - & - & 869 & 869 \\
Barmer & - & 19.64 & - & 19.64 \\
Jalor & - & - & 71 & 71 \\
Total & 18.66 & 210.55 & 1132 & 1361.21 \\
\hline
\end{tabular}

*including Hanumangarh 
Zone I : This is the main canal irrigated zone in arid Rajasthan where major input of surface water come from more humid region. About $60 \%$ area of Sri Ganganagar district, 50\% area of Bikaner district and $25 \%$ area of Jaisalmer district in the northwest lie in this zone.

Zone II : This region in 52\% area of arid Rajasthan has a system of repetitive micro-hydrology, with a primitive or no stream network. Churu, Jhunjhunun, Sikar, Nagaur, Jodhpur and parts of Bikaner, Jaisalmer and Barmer districts fall within this zone.

Table 2: Estimated present water demand ( $\mathrm{mcm})$ of arid Rajasthan (CAZRI, 1990)

\begin{tabular}{|c|c|c|c|c|c|}
\hline \multirow[t]{2}{*}{ Demand for } & \multicolumn{5}{|c|}{ Year } \\
\hline & 1981 & 1991 & 1995 & 2001 & 2011 \\
\hline $\begin{array}{l}\text { Human } \\
\text { consumption } \\
\text { @ } 40 \text { lpd* }\end{array}$ & 196.85 & 236.06 & 261.82 & 289.23 & 349.02 \\
\hline $\begin{array}{l}\text { Livestock } \\
\text { consumption } \\
\text { @ } 301 \mathrm{lpd}\end{array}$ & 249.00 & 290.00 & 308.00 & 332.50 & 376.00 \\
\hline $\begin{array}{l}\text { Irrigation } \\
@ 0.30 \mathrm{~m} \mathrm{ha}^{-1} \\
\mathrm{yr}^{-1}\end{array}$ & 5178.00 & 5696.00 & 5900.00 & 6265.00 & 6892.00 \\
\hline Industry & 16.00 & 17.00 & 17.50 & 18.00 & 21.00 \\
\hline
\end{tabular}

*liter per day
Zone III : This region has integrated stream network of Luni basin, occurring in Pali, Jalor and parts of Jodhpur and Barmer districts.

The total surface water resources excluding IGNP (Indira Gandhi Nahar Pariyojna) of arid zone of Rajasthan is $1361 \times 10^{6} \mathrm{~m}^{3}$ which is equivalent to $7.2 \mathrm{~mm}$ in depth or $7200 \mathrm{~m}^{3} \mathrm{~km}^{-1}$ in the region. Large numbers of tanks, reservoirs, minor irrigation dams and check dams have been constructed to store runoff water during monsoon period. In western Rajasthan, 550 storage tanks in the capacity ranging from less than $1.51 \times 208 \times 10^{6} \mathrm{~m}^{3}$ are functional with total utilizable capacity of nearly $1169.28 \times 10^{6} \mathrm{~m}^{3}$ for providing irrigation in $0.102 \times 10^{6}$ ha land. Out of these, six reservoirs viz., Jaswantsagar, Sardar Samand, Jawai, Hemawas, Ora and Bankali, are the major irrigation tanks with capacity of irrigation of more than 4000 ha each. Jawai is the main source of drinking water supply to many towns and villages. Tables 1 and 2 present surface water resources and the estimated water demand for the arid Rajasthan respectively.

The study (Table 2) indicates increase in demand from all sectors but much higher decadal demand from irrigation sector than from human and livestock sectors.

Table 3: Cropped area and stage of groundwater development for arid Rajasthan

\begin{tabular}{|c|c|c|c|c|c|c|}
\hline Districts & $\begin{array}{l}\text { Total area } \\
\left(\mathrm{km}^{2}\right)\end{array}$ & $\begin{array}{l}\text { Total cropped } \\
\text { area }\left(\mathrm{km}^{2}\right)\end{array}$ & $\begin{array}{l}\text { Total irrigated } \\
\text { area }\left(\mathrm{km}^{2}\right)\end{array}$ & $\begin{array}{c}\text { Net annual } \\
\text { groundwater } \\
\text { availability }(\mathrm{mcm})\end{array}$ & $\begin{array}{l}\text { Existing gross } \\
\text { groundwater } \\
\text { draft }(\mathrm{mcm})\end{array}$ & $\begin{array}{c}\text { Stage of } \\
\text { groundwater } \\
\text { development }(\%)\end{array}$ \\
\hline Barmer & 28173 & 16504 & 1505 & 250 & 256 & 102 \\
\hline Bikaner & 30356 & 14653 & 2284 & 198 & 145 & 73 \\
\hline Churu & 13859 & 11408 & 581 & 198 & 117 & 59 \\
\hline Sri Ganganagar & 10930 & 9068 & 7869 & 199 & 134 & 67 \\
\hline Hanumangarh & 9703 & 8827 & 5499 & 195 & 165 & 85 \\
\hline Jaisalmer & 38392 & 4674 & 907 & 53 & 40 & 75 \\
\hline Jalor & 10566 & 7409 & 2022 & 424 & 827 & 195 \\
\hline Jhunjhunun & 5917 & 6097 & 2426 & 243 & 420 & 173 \\
\hline Jodhpur & 22564 & 12278 & 1766 & 393 & 661 & 168 \\
\hline Nagaur & 17644 & 13654 & 2948 & 628 & 842 & 134 \\
\hline Pali & 12331 & 5829 & 1121 & 413 & 330 & 80 \\
\hline Sikar & 7742 & 6716 & 2719 & 325 & 345 & 106 \\
\hline Total & 208177 & 117117 & 31647 & 3519 & 4282 & 121.6 \\
\hline
\end{tabular}




\section{Groundwater Resources}

The quantity and quality of groundwater (moderate to highly saline) in this region is not sufficient even for drinking purposes. Adominantly sandy terrain and disorganized drainage network (drainage density as low as $0.3 \mathrm{~km} \mathrm{~km}^{-2}$ ), and recurring droughts constantly exert pressure on groundwater resources. An analysis of stages of groundwater development (Table 3 ) under cropped and irrigated area indicated that in six districts of western Rajasthan, the stage of groundwater development has exceeded $100 \%$. Number of safe blocks has been significantly reduced.

\section{Impact of Drought on Ground Water}

Analysis of rainfall occurrences and droughts revealed that during severe drought in the year 2002, state received just $215.3 \mathrm{~mm}$ rainfall against the normal of $462.4 \mathrm{~mm}$. The overall state rainfall deficit was $-53.4 \%$ with a range from $-87.9 \%$ in Bikaner district to $-24.8 \%$ in Churu district. 15 out of 32 districts of the state received scanty rainfall ( $-60 \%$ or less) and 17 districts received deficient rainfall. Drinking water situation was worse in rural areas. Over 50 percent of the hand pumps in the rural areas got dried up affecting nearly 27,000 villages. The availability of drinking water was alarming in Barmer, Siwana, Mandal, Parbatsar, Jaitaran, Pali, Ajmer, Rajsamand and Fatehsagar, where water was supplied once in 72 hours. Another estimate revealed that the groundwater levels are declining in 9 out of 12 districts of arid Rajasthan since 1984. Groundwater table in the eastern part of Jalor and Pali districts shows a decline rate of more than $0.50 \mathrm{~m}_{\text {year }}{ }^{-1}$. In Jodhpur, Jhunjhunun, Nagaur and Sikar districts, groundwater decline rate is $0.44-0.48 \mathrm{~m}^{\text {year }}{ }^{-1}$ and in Barmer, Churu and Jaisalmer districts it is less than $0.20 \mathrm{~m}$ year $^{-1}$.

\section{Future of Groundwater Scenario}

Future projection of ground water utilization were worked out for the year 2010, 2015, 2020 and 2025 considering the average growth rate @ $3.20 \%$ compounded annually (Table 4). Though, the present actual growth rate is higher, the data on utilizable recharge of the year 2001 are considered constant.

The projections indicate that status of ground water resource is very grim even when the projections are on the lower side.

\section{Water Requirement under Climate Change}

As per General Circulation Models (GCMs) with various scenarios of greenhouse gases emission, the globally averaged surface temperature is projected to increase by 1.4 to $5.8^{\circ} \mathrm{C}$ over a period of 1990 to 2100 and for Indian subcontinent, the model suggests a rise in annual mean surface temperature of 2.0$3.5^{\circ} \mathrm{C}$ by 2090 . A study at CAZRI during 2013 found that normal average annual evapotranspiration of the Rajasthan State is estimated as $1701 \mathrm{~mm}$. As small as $1 \%$ increase in temperature will enhance the evapotranspiration demand by $11.7 \mathrm{~mm}$ on annual basis. It may cause an additional annual water demand of $718 \mathrm{mcm}$ and 2,250 $\mathrm{mcm}$ for the whole state based on net irrigated area $\left(61,345 \mathrm{~km}^{2}\right)$ and total cropped area $\left(1,92,302 \mathrm{~km}^{2}\right)$ respectively (total available utilizable ground water for whole Rajasthan is 11,159 $\mathrm{mcm}$ and increase of $1 \%$ in temperature will put additional stress of $6.43 \%$ to $20.16 \%$ on existing groundwater resources). This may reduce number of safe districts from 6 to 3 and bring additional districts in the category of 'critical' and 'overexploited'. The satellite images of Rajasthan show a total wetland area of $3,450 \mathrm{~km}^{2}$ which includes $1,239 \mathrm{~km}^{2}$ ha as natural and $2,210 \mathrm{~km}^{2}$ as man-made. Increase in evaporation due to global warming will cause additional annual water loss of $40.4 \mathrm{mcm}$ for $1 \%$ increase in

Table 4: Projected groundwater scenario for arid Rajasthan

\begin{tabular}{lrrrrrr}
\hline & \multicolumn{5}{c}{ Year } \\
\cline { 2 - 7 } & \multicolumn{1}{c}{2001} & 2005 & 2010 & 2015 & 2020 & 2025 \\
\hline Utilizable Ground Water Recharge (mcm) & 3519 & 3519 & 3519 & 3519 & 3519 & 3519 \\
Net Ground Water Utilized (mcm) & 4282 & 4856.97 & 5685.43 & 6655.22 & 7790.42 & 9119.25 \\
Balance Ground Water (mcm) & -763 & -1337.97 & -2166.43 & -3136.22 & -4271.42 & -5600.26 \\
Ground Water Development stage (\%) & 121.7 & 138.02 & 161.56 & 189.12 & 221.38 & 259.14 \\
\hline
\end{tabular}


temperature. Since this state is not blessed with good perennial river systems, any increase in water demand requires careful planning for future water resource development.

\section{Arid Environment and Vegetation}

Despite inhospitable and harsh climate, as well as anthropogenic pressures, Indian arid zone has 682 species belonging to 352 genera and 87 families. Some 63 species are introduced belonging to 37 genera and 9 families. This floristic wealth is contributed from various regions of the world: $37 \%$ species are African elements, $20.6 \%$ are species, oriental, $14 \%$ are tropical and $10.3 \%$ are cosmopolitan. Compared to other deserts of the world, this desert has higher number of endemic species, i.e. 6.4\%. Poaceae and Leguminoseae are the largest species. Some 331 species of 44 families are ephemerals, of these 52 species are winter annuals; 17 are winter and monsoon annuals and 282 species (38.7\% of total flora) monsoonal, belonging to 184 genera and 44 families. Of these, maximum monsoonal ephemerals are from family Poaceae (50), followed by Fabaceae (25), Cyperaceae (20), Asteraceae (20), Euphorbiaceae (15), Convolvulaceae (13), Acanthaceae (11).

Thus, arid zone of India not only has diverse communities in a large variety of environmental situations, but these species also have immense variability at genetic level making it a new-found micro-hot spots of diversity. Industrialization, mining, intensification of agriculture, irrigation, tourism and urbanization have assumed enhanced pace that has posed a major threat to desert vegetation. Cutting of more trees of Tecomella undulata for making carved furniture, harvesting of more of Lasiurus sindicus for animals and collection of more seeds of Cirullus colocynthis for oil has brought these to abysmally low populations in the last 30 years so much so that these are now included in the list RET \& E (Rare, Endangered, Threatened and Extinct) species. Detailed studies of vegetation in the Indian Thar Desert in the past over 60 years have revealed that degraded and non-degraded habitats markedly differ in their structure and composition (Table 5).

\section{Status of Vegetation Degradation}

Increase in human and livestock population has led to fragmentation of land holding, cultivation of marginal lands and decline in land fallowing resulting in increased removal of vegetation culminating in seed or propagule loss. Over the time, such degradation causes increase in therophytes and finally yield declines 2-4 times, with annual grasses being the major contributors. Basal cover and density decline, range condition becomes poor, woody perennials deteriorate and disappear, ecological status changes with decline in vegetation health, dominance-diversity changes and finally ends up in barren landscape. Appraisal of grazing lands in Indian arid zone, through field based surveys undertaken by CAZRI revealed that $70 \%$ of them are very severely degraded, $13-14 \%$ severely degraded, $7 \%$ moderately degraded, 5\% slightly degraded and only $3-4 \%$ are non degraded.

\section{Remote Sensing of Degraded and Dry Arid Vegetation}

The institute carried out a study on the usefulness of remote sensing technology to assess desert vegetation (mix of green, senescent and dry vegetation) using PD54 index (Pickup et al., 1993). The exercise was carried out to assess dried vegetation resulting from drought of 2002 in Shergarh tehsil in Jodhpur District, using PD54 and NDVI (Normalized Difference Vegetation Index) on real time satellite and ground data, which revealed PD54 a more accurate index. This is so because PD54 is independent of "greenness" of vegetation, an index that is required to reliably estimate cover at different time intervals. PD54 output showed good grass cover after a good rainfall in protected area in October, 2001 which NDVI could not detect. After failure of rains in September, 2002, the protected paddock at Shergarh still had better grass cover while adjoining open grazing land was severely degraded with poor cover. This difference in ground vegetation could not be detected by NDVI in September 2002 scene. This comparison of outputs of PD54 with NDVI proved the efficacy of PD54 index in detecting vegetation condition as existing on the ground.

\section{Extent and Impacts of Mining}

Of the 65 major and 22 minor minerals produced in India, Rajasthan produces 42 major and 22 minor minerals. Wollastonite and Jespar are only in Rajasthan, which has $97 \%$ of zinc, $95 \%$ of gypsum, $96 \%$ of fluorite, $70 \%$ of sand stone and limestone, $89 \%$ of asbestos, $90 \%$ of marble, $70 \%$ of calcite, $80 \%$ 


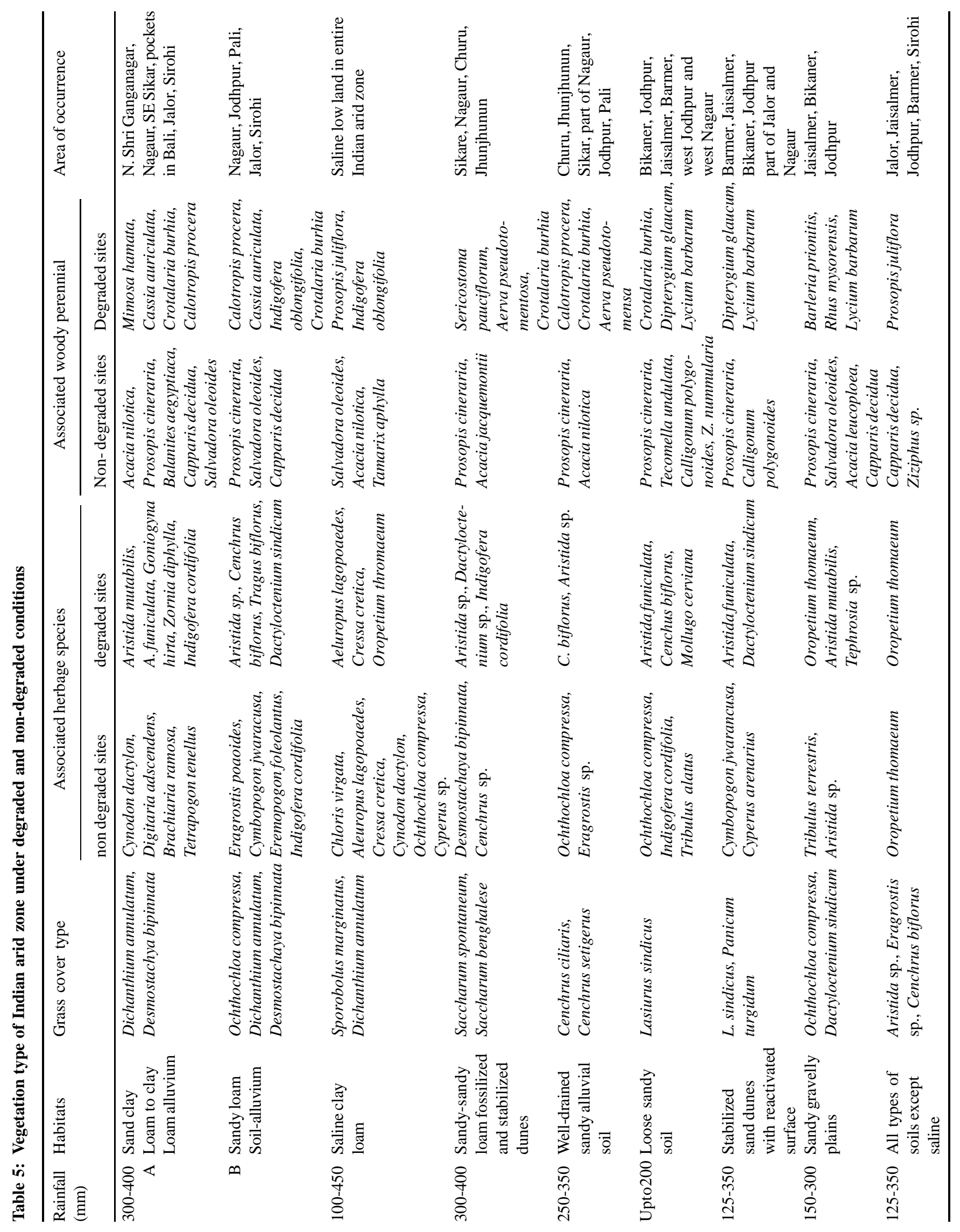


Table 6: Species planted at Lignite backfill in Barmer, Rajasthan

\begin{tabular}{ll}
\hline Type of vegetation & Plant species \\
\hline Trees & $\begin{array}{l}\text { Acacia senegal, Acacia tortilis Azadirachta indica, Leucaena leucocephala, Parkinsonia aculeata, Prosopis } \\
\text { cineraria, Salvodora oleoides, Tecomella undulate }\end{array}$ \\
Shrubs & $\begin{array}{l}\text { Cassia angustifolia, Circidium floridum, Dichrostachys nutans, Tamarix aphylla, Ziziphus rotundifolia, } \\
\text { Acacia nubolophospermum mopane }\end{array}$ \\
Grasses & Cenchrus setigerus, Cenchrus ciliaris, Lasiurus sindicus \\
Crops & Pennisetum glaucum \\
Medicinal Plants & Cassia angustifolia \\
Vegetables & Cucumis callosus var. Agrestis, Cucumis callosus var. Momordica, and Citrullus fistulosus \\
\hline
\end{tabular}

and of soapstone deposits of India. Mineral wastes dumped often on adjoining fertile lands are known to create problems of environmental concern. Therefore, it becomes essential to find out techniques of rapid rehabilitation modules of mining of different minerals. CAZRI has successfully demonstrated the rehabilitation of few such lands of limestone, gypsum and lignite mines.

\section{Rehabilitation of Lignite Mining Backfill}

In view of drastically disturbed land surface due to mining, land shaping and characterization of spoil surface became the first step so as to decide about the soil additives for profile modification. Based on soil and climatic conditions, suitable plant species, were selected and planted on the mine site (Table 6). After plantation, the follow up procedures included irrigation, weeding and after care. Survival of species planted at lignite mine spoil was $82.82 \%$. Maximum growth was observed in Parkinsonia aculeata. MidFebruary to March has proved to be better plantation season in lignite backfill. Direct seeding of Senna (Cassia angustifolia) and intercropping perennial grasses (Cenchrus ciliaris and Lasiurus sindicus), Pearl millet (Pennisetum glaucum) as well as vegetables has proved successful.

\section{Rehabilitation of Gypsum Mining Area}

Revegetation of gypsum mine spoils examined both mined and unmined areas and established assessments of existing vegetative cover and the quality of native soils and mine spoils. Tests were made on the effect of the use, and conservation, of available water through rainwater harvesting, amendment application (for physical and chemical spoil modification with addition of farmyard manure), plant establishment protocols, and the selection of appropriate species. Although the mine spoils are deficient in organic matter and phosphorus, they possess adequate amounts of other nutrients. Total boron concentrations $(5.0 \mathrm{mg}$ $\mathrm{kg}^{-1}$ ) in both the topsoil and mine spoil indicate potentially phytotoxic conditions. Electrical conductance of mine spoil is 6-10 times higher than for topsoil with a near-neutral $\mathrm{pH}$. Populations of spoil fungi, Azotobactor, and nitrifying bacteria are low. The soil moisture storage in rainwater harvesting plots increased by $8 \%$ over the control and $48 \%$ over the unmined area. As a result of rehabilitation efforts, mine spoils show a steady build up in organic carbon, and $\mathrm{P}$ and $\mathrm{K}$ due to the decomposition of farmyard manure and the contribution of nitrogen fixation by the established leguminous plant species. The rehabilitation protocol used at the site has been successful.

\section{Rehabilitation of Limestone Mining Area}

Revegetation of limestone mine spoils near Barna, northwest arid India was carried out using a combination of rainwater harvesting techniques, soil amendment application approaches, plant establishment methods and the selection of appropriate species of trees, shrubs and grasses. The rehabilitation protocol used at the site appears to have been successful because plant self-regeneration is occurring. The increased diversity of woody perennials resulted in 'dominance' being better shared among species and 'evenness' being increased within the plant community elements. The early to midsuccessional trends continued for six years following initial rehabilitation. Study developed methods for the 
rehabilitation of lands mined for limestone and has also resulted in an understanding of rehabilitation processes in arid regions.

Salinity in the arid regions is a known problem. A major programme has also been initiated in the coastal saline area of Bhuj to identify the halophytes that can be used for reclamation of both coastal and inland salinity.

\section{Erosion Processes in Arid Rajasthan and their Measurement}

\section{Wind Erosion}

Wind erosion is a major land degradation process in the arid and semi-arid regions of the world. It affects about $41 \%$ land area in the world and about $12.4 \%$ in India. Removal of soil particles by wind is very active in the Indian Thar Desert. During severe dust storm events, the suspended particles may get transported by air over hundreds of kilometre and form a blanket of dust haze over the Indo-Gangetic plains and surrounding area.

\section{Wind Erosion and Soil Loss}

Extent of soil loss through wind erosion in western Rajasthan has been studied by several researchers since 1978. Earlier researches based on surface

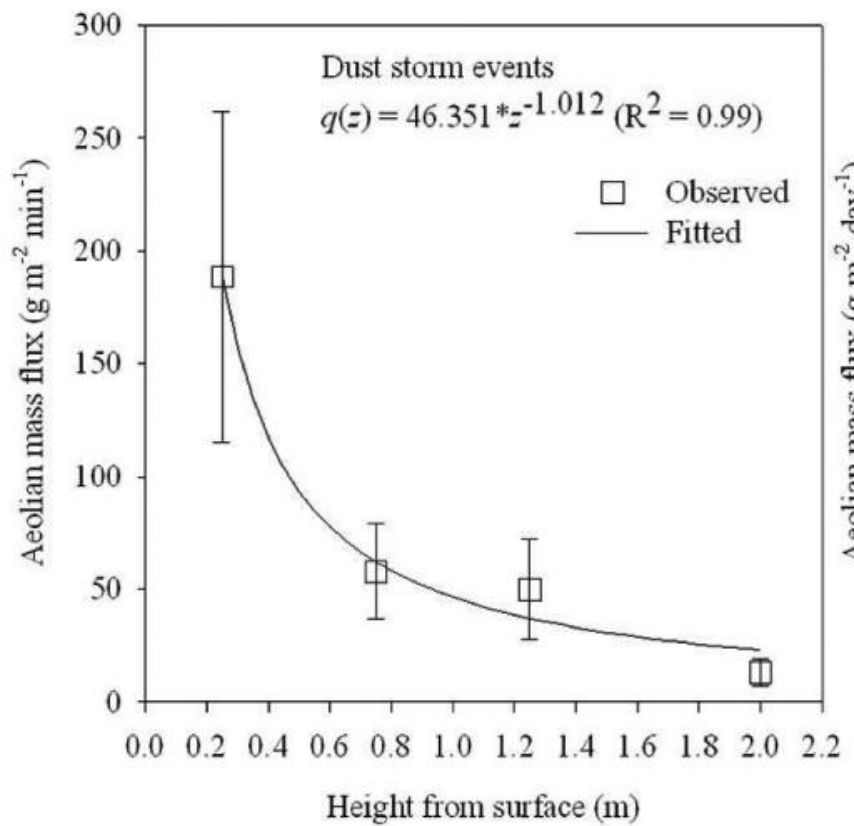

manifestations suggested physical indicators to suggest severity of land degradation. At the field level, erosion pins were used to measure soil loss and it was found that within a period of 75 days from April to June, 9 $\mathrm{cm}$ of top soil may be removed from bare sandy plains, which may be as high as $37 \mathrm{~cm}$ from bare sand dunes. During extreme dry conditions from April to June, soil loss was $31.2-61.5 \mathrm{~kg} \mathrm{~m}^{-2}$. Dust blowing in the zone of three meters above the soil surface measured by using fixed dust catcher revealed that on a stormy day soil loss varied from $50 \mathrm{~kg} \mathrm{ha}^{-1}$ to $420 \mathrm{~kg} \mathrm{ha}^{-1}$.

Workers at CAZRI, based on above research results, used similar type of dust catcher and reported soil loss of $827 \mathrm{~kg} \mathrm{ha}^{-1}$ at the overgrazed site at Jaisalmer and $240 \mathrm{~kg} \mathrm{ha}^{-1}$ at the controlled grazing site at Chandan during summer of 2004. In a recent study, institute developed a wind erosion sampler to collect eroded aeolian masses during several dust storm and wind erosion events. Based on wind erosion map prepared by CAZRI and published in 2000, following sites were selected for the purpose; Jaisalmer (moderately affected), Khuiyala, Jaisalmer (very severely affected) and Bhujawar village at Jodhpur (slightly affected).

The mass-height profile curves during dust storm events and periodical observations of wind erosion recorded at Jaisalmer are presented in Fig. 6. These

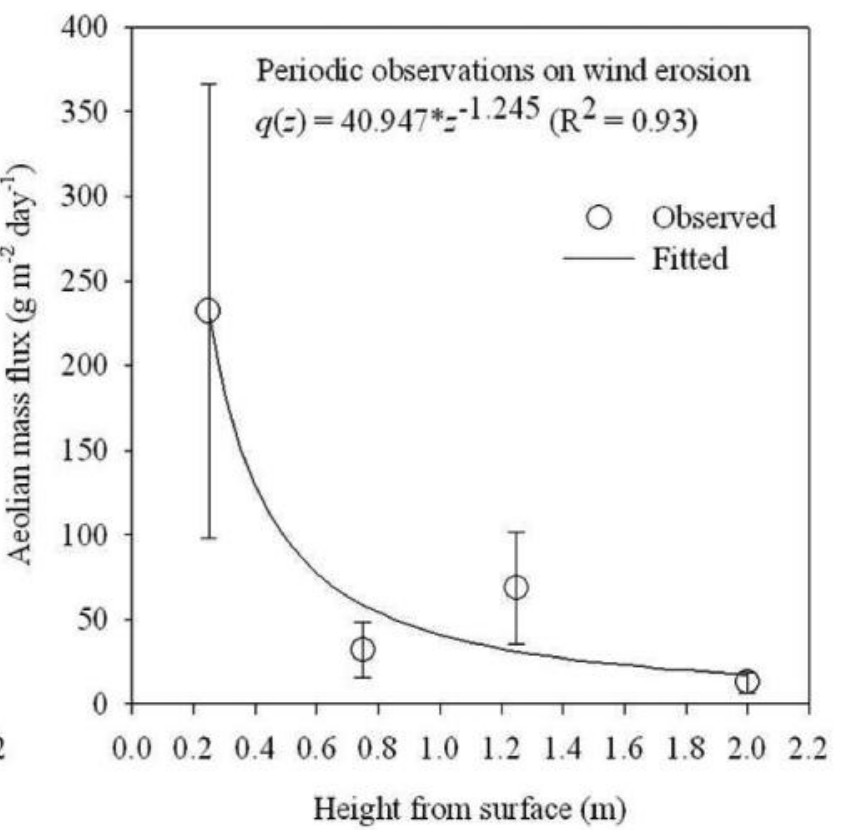

Fig. 6: Mass-height profile of wind eroded aeolian masses of (a) dust storm events and (b) periodical observations on wind erosion events in the Indian Thar Desert at Jaisalmer during June to September, 2009 
figures show how aeolian mass flux reduced with height above the surface. Characteristically it was also found that variation of observed mass flux at lower most sampling height $(0.25 \mathrm{~m})$ was more than those observed for higher sampling heights. On an average, mass flux at $1 \mathrm{~m}$ height, as indicated by parameter 'a', was $46.351 \mathrm{~g} \mathrm{~m}^{-2} \mathrm{~min}^{-1}$ during dust storm events whereas it was $40.947 \mathrm{~g} \mathrm{~m}^{-2}$ day $^{-1}$ during periodical observations on wind erosion from June to September, 2009. Magnitude of parameter 'b' was comparatively higher during periodical observations on wind erosion than during dust storm events. This indirectly indicated that eroded mass fluxes were more differentiated with height during periodical observations on wind erosion than during dust storm events.

The most severe dust storm of the year, 2009 occurred 15th June, which was one of the most severe dust storms over last two decades. Wind speed during this event was $50-55 \mathrm{~km} \mathrm{~h}^{-1}$ and it started at $4: 00 \mathrm{pm}$ and lasted for around half an hour. The second most severe dust storm events of the year 2009 occurred on $17^{\text {th }}$ June, just two days after the first severe dust

Table 7: Wind erosion/dust storm events recorded during 2009 and 2010 at Jaisalmer and the approximate soil loss during each event

\begin{tabular}{lccc}
\hline $\begin{array}{l}\text { Name of Time of occurrence } \\
\text { the obser- } \\
\text { vations }\end{array}$ & $\begin{array}{r}\text { Duration } \\
\text { in suspen- } \\
\text { sion mode } \\
\left(\mathrm{kg} \mathrm{ha}^{-1}\right)\end{array}$ & $\begin{array}{c}\text { Soil loss } \\
\text { soil } \\
\left(\mathrm{kg} \mathrm{ha}^{-1}\right)\end{array}$ \\
\hline $\begin{array}{l}\text { Dust storm events (DSE) } \\
\text { DSE-1 June 15, 2009 }\end{array}$ & 30 min & 389 & 1166 \\
DSE-2 June 17, 2009 & 20 min & 246 & 466 \\
DSE-3 June 24, 2009 & 15 min & 19 & 58 \\
DSE-4 July 09, 2009 & 25 min & 128 & 1485 \\
DSE-5 July 14, 2009 & 15 min & 16 & 30 \\
DSE-6 June 5, 2010 & 20 min & 503 & 870 \\
Periodical Observations on Wind Erosion (POWE) & \\
POWE-1 June 25-July 2, 2009 & 7 days & 23 & 30 \\
POWE-2 July 15-July 30, 2009 & 16 days & 203 & 3244 \\
POWE-3 July 31-Aug 18, 2009 & 19 days & 255 & 5287 \\
POWE-4 Aug 19-Sept 3, 2009 & 15 days & 49 & 68 \\
POWE-5 Sept 4-Sept 23, 2009 & 20 days & 39 & 188 \\
POWE-6 April 17-May 5, 2010 & 18 days & 273 & 366 \\
POWE-7 May 6-June 4, 2010 & 29 days & 953 & 1434 \\
\hline
\end{tabular}

storm of the year. The severity of the second dust storm event in terms of the soil loss was comparatively less because of the previous day rainfall event (15.2 $\mathrm{mm})$. Besides, three more dust storm events on $24^{\text {th }}$ June, $9^{\text {th }}$ July, and $14^{\text {th }}$ July were recorded and corresponding aeolian masses were collected. During 2010, occurrence of wind erosion events were comparatively less because of good monsoon rainfall during mid- June and onwards. Two periodical wind erosion events and one dust storm event was recorded during April-June. It was observed that most of these dust storm events were of short duration (15-30 min) and occurred mostly during the evening time. Most of them were associated with drizzling at their dissipating stage. All these periodic observations were recorded and are presented in Table 7.

Soil loss in suspension mode was computed within 0.25 to $2 \mathrm{~m}$ height, whereas total soil loss was calculated from very near to soil surface $(0.01 \mathrm{~m})$ up to $2 \mathrm{~m}$ height

Computed soil loss in suspension mode during dust storm events revealed a maximum soil loss of $389 \mathrm{~kg} \mathrm{ha}^{-1}$ during dust storm event on 15-06-2009, for a 30 minutes duration. However, extrapolation of power decay model downward up to $0.01 \mathrm{~m}$ height from surface resulted in total soil loss of $1166 \mathrm{~kg}$ $\mathrm{ha}^{-1}$ during the same dust storm event. On an average, soil loss rate during dust storm events of the year 2009 was found as $17 \mathrm{~kg} \mathrm{ha}^{-1} \mathrm{~min}^{-1}$. Periodical observations on eroded soil mass revealed an average soil loss rate of $25 \mathrm{~kg} \mathrm{ha}^{-1} \mathrm{day}^{-1}$. Cumulative soil loss in suspension mode during middle of June to end of September of 2009 was $1.36 \mathrm{t} \mathrm{ha}^{-1}$ whereas total soil loss was $12.02 \mathrm{t} \mathrm{ha}^{-1}$. Following the similar approach, annual soil loss rate at Khuiyala, Jaisalmer was found $83.8 \mathrm{t} \mathrm{ha}^{-1}$, whereas it was only $1.3 \mathrm{tha}^{-1} \mathrm{yr}^{-1}$ at Bhujawar, Jodhpur. It is to be noted here that the experimental site at Jaisalmer was rocky scrub land, at Khuiyala it was open sand dunes whereas at Jodhpur it was cultivated fallow land during summer.

\section{Field Measurement of Soil Loss Through Instrumentation}

Various types of sampling devices viz., sampler, traps, catchers and collectors are used to quantify aeolian sediment load to atmosphere generated during wind erosion events. Among the wind erosion samplers, more popular ones are the Big Spring Number Eight 


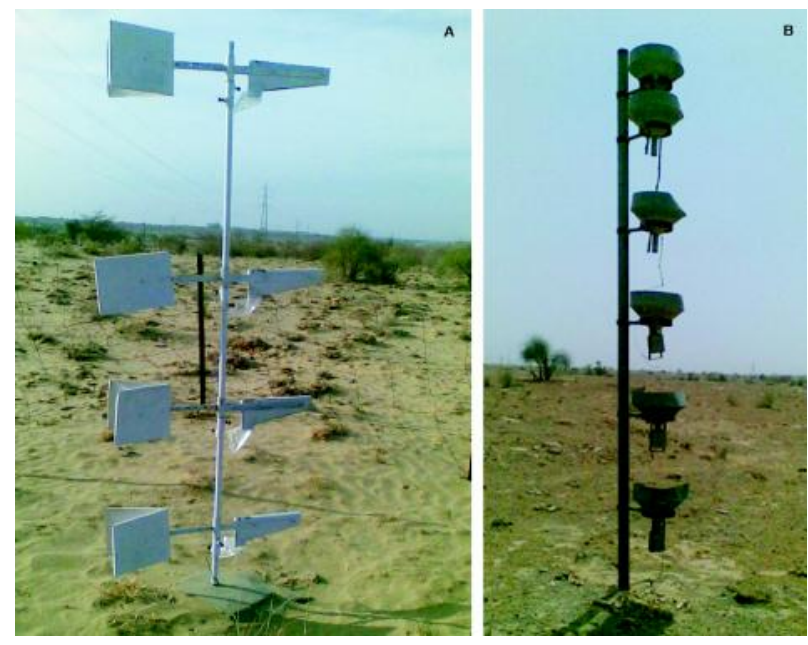

Fig. 7: Field devices to measure wind erosion process; (a) the new wind erosion sampler and (b) dust catcher

(BSNE) sampler and Modified Wilson and Cook (MWAC) sampler. Besides, several indigenous samplers like suspended sediment trap (SUSTRA), Pollate Catcher (PULCA), Saltiphone and Cox sand catchers are available in different arid regions of the world. In the Indian Thar desert, dust catcher in the design of Bagnold sampler has been used. In the following paragraphs, few of these instruments are described.

Dust catchers or wind erosion samplers are generally placed at the centre of experimental field at four different heights from ground surface as shown in Fig. 7. These samplers are of freely rotating type and have a rectangular orifice of $10 \mathrm{~cm}^{2}$, which could orient itself towards wind erosion direction. The individual samplers in the dust catcher are funnel shaped with its open top having a diameter of $0.35 \mathrm{~m}$. A metal strip of $0.089 \mathrm{~m}$ in height is attached at the top brim of the funnel with an opening area of 0.035 $\mathrm{m}^{2}$ at one side. The opening of samplers in dust catcher is fixed towards the most prevailing wind erosion direction, which is SSW in western Rajasthan. This sampler has following major advantages over dust catcher; (1) the top of wind erosion sampler is closed and therefore prevents the deposition of fine suspended particles during calm atmospheric condition after a wind erosion event, whereas it is kept open for dust catcher and (2) the wind erosion sampler is free rotating in nature, therefore can be able to collect eroded soil from any wind erosion direction, whereas the dust catcher is fixed towards a particular direction.
Wind eroded soil masses were collected in the field through wind erosion sampler during each dust storm event or local wind erosion events as well as periodically. Variation of mass-fluxes of aeolian sediments across different heights from ground surface were then fitted in power decay mass-height profile, which was found the best model for the Indian Thar desert (as shown in Eq. (1):

$$
q(z)=\mathrm{a} z^{\mathrm{b}}
$$

where, $\mathrm{q}$ is the mass flux $\left(\mathrm{M} \mathrm{L}^{-2} \mathrm{~T}^{-1}\right)$ of aeolian sediments at height $\mathrm{z}(\mathrm{L})$ from ground surface; ' $\mathrm{a}$ ' and ' $b$ ' are empirical constant of the equation. Total aeolian mass transport rate $\left(\mathrm{M} \mathrm{L}^{-1} \mathrm{~T}^{-1}\right)$ up to a standard height of $2 \mathrm{~m}$ has been computed through integration of Eq. (1) with lower limit of $z=0.01 \mathrm{~m}$ to upper limit of $\mathrm{z}=2 \mathrm{~m}$. The calculated mass transport rate was converted to soil loss $\left(\mathrm{kg} \mathrm{ha}^{-1}\right)$ by dividing the aeolian mass transport rate with the distance (L) of non-eroding boundaries from the sampling point and multiplying with the duration of wind erosion event (T).

While measuring the soil loss using erosion pins, properly marked iron pegs $(100 \mathrm{~cm} \times 1 \mathrm{~cm}$.) were installed at a distance of 6 meter in the form of squares. The pegs were fixed in the soil in such a way that 60 $\mathrm{cm}$ of pegs are projected above the ground level. This height was taken up as reverencer point. Sand deposition or removal was monitored from the reference point of each peg.

\section{Water Erosion}

\section{Fluvial Processes Measurements}

In arid regions, water erosion in the form of sheet, rill and gully erosion is usually a problem in the areas receiving average annual rainfall exceeding $350 \mathrm{~mm}$. However, fluvial processes would function much less frequently and more episodically than the aeolian processes but their impacts on landforms and society are large in the Thar Desert. Several major flood causing rainfalls occurred during the last three decades; during 1975, 1979, 1983, 1990 and 2006. In 2006, several stations in the northern part of Barmer district and adjoining part of Jaisalmer district were inundated because of unprecedented rainfall of 300$400 \mathrm{~mm}$ during 17-24 August. 
Quantitative Monitoring of Arid Zone Fluvial Forms and Processes in Arid Rajasthan

The institute carried out a field based measurement of water erosion in an upland stream catchment (9.3 ha, second order ephemeral channel (1.0-1.4 km long and 1.0-1.5 m deep) developed on rocky upland with a hill-rocky/gravelly pediment-colluvial plain sequence at Agolai near Jodhpur town. The region receives an annual rainfall $\sim 250 \mathrm{~mm}$, however, between 2005 and 2012 , there were occasional annual rainfalls of $>350$ $\mathrm{mm}$ with more number of rainy days. The study involved measuring erosion from the hill-slopes, gullied channels and stream banks, as well as particle movement after a measured rainfall event, following a set of basic methodology. The procedures are, use of a standard Theodolite to measure and construct hypsometric curves using height along and across the main channel before and after every run-offgenerating rainfall events, long profile measurement at 104 fixed locations with reference to a benchmark, and channel cross profiles at 19 locations. Discharge was calculated at 6 cross section locations using the Manning equation

$$
\mathrm{Q}=1 / \mathrm{n} \mathrm{AR}^{2 / 3} \mathrm{~S}^{1 / 2}
$$

Where $\mathrm{Q}=$ discharge $\left(\mathrm{m}^{2} \mathrm{~s}^{-1}\right), \mathrm{A}=$ crosssectional area $\left(\mathrm{m}^{2}\right), \mathrm{R}(\mathrm{A} / \mathrm{P})=$ hydraulic radius $(\mathrm{m})$, $\mathrm{P}=$ wetted perimeter $(\mathrm{m}), \mathrm{S}=$ average gradient $(\mathrm{m} /$ $\mathrm{m})$ and $\mathrm{n}=$ Manning's roughness coefficient.

A rough estimate of velocity was made by measuring the time required for a float to travel a fixed distance along the stream at selected crosssections. To monitor bed load movement along the main channel, key particles $>2 \mathrm{~mm}$ size were coloured and were placed at different locations of the channel. All the particles were grouped under 3 weight groups of $>100 \mathrm{~g}, 51-100 \mathrm{~g}$, and $<50 \mathrm{~g}$. For understanding aspects of shape factor and sediment movement, the degree of flattening (flatness index) of each particle was calculated using the equation: $\mathrm{FI}=\mathrm{E} / \mathrm{L}$ X 100 (where FI = Flatness index, $\mathrm{L}=$ major axis (length) of pebble, $1=$ minor axis (width); $\mathrm{E}=$ breadth of pebble; $\mathrm{r}=$ smallest radius of curvature. On the basis of FI, the particles were grouped into three categories of FI: $<25,26-50$ and $>50$.

During 2007, two high rainfall events of $42 \mathrm{~mm}$ and $52 \mathrm{~mm}$ occurred in the catchment which generated measurable runoffs with peak discharge of $20 \mathrm{~m}^{3} \mathrm{~s}^{-1}$ (upstream) and $13 \mathrm{~m}^{3} \mathrm{~s}^{-1}$ (downstream). These forces moved the bedload sediments to distances of $43 \mathrm{~m}$ $141 \mathrm{~m}$ in the upstream, 6-28 $\mathrm{m}$ in the middle reach and $63-95 \mathrm{~m}$ in the lower reach.

The long and cross profile measurements showed a sequence of alternate deposition and erosion throughout the channel with a marked asymmetry in the form of concavity (scours) and convexity (fills) in the lower reach. Hypsometry curves revealed maximum erosion $(7.7 \mathrm{~cm})$ in the upper reach and aggradation $(2.90 \mathrm{~cm})$ in the lower reach. Cross profiles measurement showed bank cuts $(6 \mathrm{~cm})$ and vertical incision $(1-2 \mathrm{~cm})$ on the rocky-gravely $\mathrm{V}$ shaped valley in the upper reach, incision $(4-30 \mathrm{~cm})$ and localized higher deposition $(10-12 \mathrm{~cm})$ in the narrow $(<1 \mathrm{~m})$ and deep $(1.5 \mathrm{~m}) \mathrm{U}$ shaped valleys in the middle reach and mainly deposition $(13 \mathrm{~cm})$ on the wide (1-4 m) and shallow channels ( 0.1 to $0.2 \mathrm{~m})$ in the lower reach. The rain storms of 1-2nd and 1314th August showed more impact on the bed load movement. Analysis of particle weight and distance moved by them indicated, $62.5 \%$ particles in the upper reach (av. $\mathrm{wt}=214 \mathrm{~g}), 87 \%$ in the middle reach (av. $\mathrm{wt}=129.7 \mathrm{~g})$ and $26.4 \%$ in the lower reach $(\mathrm{av} . \mathrm{wt}=$ $83.1 \mathrm{~g})$ moved less than $50 \mathrm{~m}$ distance. Among the lighter weight group $(<50 \mathrm{~g})$ the highest $(124.56 \mathrm{~m})$ and lowest displacement $(28.80 \mathrm{~m})$ were recorded at upper and middle reach while the maximum displacement (60-70m) of heavier particles (> 100 g), occurred in the lower reaches. Similarly, less flat particles $(\mathrm{FI} \sim 0-25)$, moved maximum in the lower and minimum in the middle section. The more flat particles $(F I=>50)$ moved maximum distances in the upper reach. In general it was found that particles (< $50 \mathrm{~g}$ weight $)$ and less flat $(\mathrm{FI}=<25)$ experienced the highest displacement (95-106 m). These spatio temporal bed load movements presented a view of cascading flow as generally is noticed after desert floods and is crucial for modelling and conservation of structures along ephemeral channels (Moharana and Kar, 2010).

\section{Simulation of a Defunct Drainage System after a Rare Desert Flood in Western Rajasthan}

The sandy terrain of Jaisalmer and Barmer districts experienced a rare flood during 17-24 August 2006 when various stations received, on an average, 150 
to $450 \mathrm{~mm}$ rainfall within 1-2 days. Investigation was carried out by CAZRI scientists for a genesis of impact of such incidences. It was found that the sandy and dry north-western part of Barmer district got exceptionally high runoff discharge as some of the stations received 3 fold rise in normal rainfall. The catchment areas have a number of dry streams that are partly covered by low sand dunes. It was found that in the flow path of the flood water in the upstream areas, there were a good number of structures to conserve the usually meagre flow which breached almost simultaneously under the high intensity rainfall, resulting in a huge surge of water through the dry channels. Some abandoned channels were also revived. To understand the flow path of such surging water, a GIS and remote sensing based channel simulation was carried out for the affected area. It revealed the part revival of a hitherto unknown major right-bank tributary of the Luni River. Earlier it was believed the Lik River, originating near Pokaran in Jaisalmer was the westernmost right-bank tributary of the Luni, but this flood revealed a longer rightbank tributary from near Mehreri in Jaisalmer district that flowed past Bisu, Nagurda and then carried the waters of Rohili River catchment from Shiv-Kotara area and other streams from the Baisala hills catchment and the Luni hills catchment, to Kawas and beyond. Beyond Kawas, the stream possibly used to meet the Luni to the south of Sindri, but got subsequently dismembered by high sand dunes.

Thus, the study indicated that even in a desert, the old and the abandoned stream courses (palaeochannels) are potential sites for disaster if their passage is obstructed. The study revealed the exhumation of a major drainage network in the area that was buried under sand for long due to paucity of rainfall. The sediments washed down from uplands contained micaceous clay having 8-15 times higher $\mathrm{N}$ (880-3234 kg ha-1), 3-4 times higher $\mathrm{P}$ (20-55 kg $\left.\mathrm{ha}^{-1}\right)$ and 2-9 times higher $\mathrm{K}\left(270-1249 \mathrm{~kg} \mathrm{ha}^{-1}\right)$ than in the underlying soils, making the land much fertile than before.

During 4-6 July 2007, the upper Luni catchment received a short burst of high-intensity rain. The dry Jaswant Sagar dam got filled up in a single day (6 July), and breached the next morning. Analysis by CAZRI revealed how a paleochannel of the Luni existing near Malkosni (upstream of Bala), had carried some of the Luni's discharge during the1979 flood, and became a true saviour of mankind after the dam breached on 7 July 2007.

\section{Quantification of Soil Erosion in Arid Gujarat}

In arid region of Gujarat, annual rainfall is very low (with average rainfall of $350 \mathrm{~mm}$ in Kachchh district) and erratic in nature, which is the major cause for scarcity of surface water resources. In addition, water erosion is the most dominant land degradation process, affecting about $43 \%$ of the total area (mostly in croplands), followed by salinity (38\%), while vegetation degradation (10\%) and wind erosion (5\%) covered smaller areas. Of the total area of Gujarat, about $17.1 \%$ area is affected by very severe water erosion, while $9.9 \%$ area is under severe erosion and $5.2 \%$ under moderate erosion.

A study was undertaken to create a quantitative database on water and sediment flow in a watershed at Kukma watershed, within which the farm land of Regional Research Station (RRS), CAZRI is located. The objective was to make effective intervention to conserve and utilize the excess run-off that drains out of farm pond during high intensity rainfall events. The mean annual rainfall of the study area is $396 \mathrm{~mm}$ with standard deviation of $288 \mathrm{~mm}$ based on 26-year period (1988-2013) data; more than $90 \%$ annual rainfall is received during June to September only within 2-3 days of very high intensity storms.

The study created spatial databases on rainfall and other land resources using GIS and Remote Sensing platforms; daily rainfall data of three-year period (2011-2013) for single rain gauge station of the Kukma watershed through Agro-meteorological Observatory located in the RRS-CAZRI campus, soil map (from CAZRI), land use/land cover (developed from the Google Earth image,2012), topography extracted from Shuttle Radar Topographic Mission data (downloaded from US Geological Survey website, USGS, 2004). The GIS analysis and operations were performed using Integrated Land and Water Information System (ILWIS) software (version $3.2)$.

The Universal Soil Loss Equation (USLE) model was used to estimate the average annual soil loss (tonnes/ha/year), computed by using the following USLE model. 


$$
A=R \times K \times L S \times C \times P
$$

Where, $\mathrm{A}=$ average annual soil loss (tonnes ha $^{-1}$ year $\left.^{-1}\right) ; \mathrm{R}=$ rainfall erosivity factor $(\mathrm{MJ} \mathrm{mm}$ $\mathrm{ha}^{-1} \mathrm{~h}^{-1}$ year $^{-1}$ ); $\mathrm{K}=$ soil erodibility factor (tonnes ha $\mathrm{h} \mathrm{ha}^{-1} \mathrm{MJ}^{-1} \mathrm{~mm}^{-1}$ ); $\mathrm{L}=$ slope length (dimensionless); $\mathrm{S}=$ steepness factor (dimensionless); $\mathrm{C}=$ cover and management factor (dimensionless); and $\mathrm{P}=$ support practice factor (dimensionless).

\section{Factors Used for Soil Erosion Assessment}

The rainfall erosivity factor ( $\mathrm{R}$-factor) is defined as the product of total storm energy and maximum 30min intensity divided by 100 for numerical convenience, known as the $\mathrm{EI}_{30}$ index. In absence of rainfall intensity records, monthly rainfall data was used to calculate R-factor annually using following relationship.

$$
R=\sum_{i=1}^{12} 1.735 \times 10^{\left\{1.5 \log _{10}\left(\frac{P_{i}^{2}}{P}\right)-0.08188\right\}}
$$

Where, $\mathrm{R}=$ rainfall erosivity factor in $\mathrm{MJ} \mathrm{mm}$ $\mathrm{ha}^{-1} \mathrm{~h}^{-1}$ year $^{-1}, \mathrm{P}_{\mathrm{i}}=$ monthly rainfall in $\mathrm{mm}$, and $\mathrm{P}=$ annual rainfall in $\mathrm{mm}$. In the availability of single rain gauge station, one R-factor value was considered for the whole catchment in a year.

The K-factor, termed as 'soil erodibility factor', can be computed by empirical method, nomograph or $\mathrm{K}$-value triangle based on soil texture.

The slope length and steepness factor or LSfactor is a product of slope length (L) and steepness (S). In this study, L and S factors were calculated separately by using SRTM (Shuttle Radar Topographic Mission) DEM with resolution of 3 arc-second (or 90 $\mathrm{m}$ pixel size). The L-factor was estimated by technique by using the following relationship.

$$
L=\left(\frac{\lambda}{22.13}\right)^{m}
$$

Where, $\mathrm{L}=$ slope length factor (unit less); $\lambda=$ field slope length $(\mathrm{m}) ; \mathrm{m}=$ dimensionless exponent that depends on slope steepness, being 0.5 for slopes exceeding 5 percent, 0.4 for 4 percent slopes and 0.3 for slopes less than 3 percent.
The S-factor was derived for slope length longer than $4 \mathrm{~m}$ using the following equations.

$$
\begin{array}{ll}
\mathrm{S}=10.8 \sin \theta+0.03, & \mathrm{~s}<9 \% \\
\mathrm{~S}=16.8 \sin \theta-0.05, & \mathrm{~s} \geq 9 \%
\end{array}
$$

Where, $\mathrm{S}=$ slope steepness factor (unit less); and $\theta=$ slope angle (degree).

The GIS-based slope map for the study catchment was generated by applying two differential gradient filters $\left(\frac{\partial}{\partial x}\right.$ and $\left.\frac{\partial}{\partial y}\right)$ on the DEM by using ILWIS software. Then, L-factor was computed from Eqn. 3 with field slope length $(\lambda)$ value as $90 \mathrm{~m}$, and S-factor was estimated from Eqns. 4 and 5 in GIS environment using slope map of the catchment.

For computing C-factor, Google Earth image was used to classify the land use/land cover (LULC) into suitable classes. The P-factor was calculated using the land use map. In absence of any support practices, the P-factor is 1.0 (highest).

On the basis of topography (elevation, 100-150 $\mathrm{m}$ in $64 \%$ area to $200-250 \mathrm{~m}$ in the south), land slope (mild slope in 57\% area), soil texture (medium texture in $84 \%$ area) three classes of hydrologic soil group (HSG), i.e. HSG-A, HSG-B, and HSG-C were delineated. Land use/land cover (LULC) map of the watershed indicates six types, i.e. agricultural land, open scrub land, waterbody, built-up land, mining affected wasteland and cultivable wasteland. Agricultural land in $34 \%$ area and open scrub land, $32 \%$ are the major land uses. Wastelands occur in about $28 \%$ area. A curve number map was prepared by crossing HSG and LULC maps in GIS environment for the antecedent moisture conditions (AMC)-II. Highest values of the curve number $(\mathrm{CN})$ indicates the presence of water bodies in the area whereas the lowest $\mathrm{CN}$ value, i.e. 25 , occurred in northern portion. The southern hilly portion contains the $\mathrm{CN}$ value of 74.

\section{Distributed Parameters of USLE Model}

Distributed maps of the six parameters of the USLE model were prepared in GIS (Fig. 8). The computed R-factor values are 4691.01, 510.2 and 2529.02 MJ $\mathrm{mm} \mathrm{ha}^{-1} \mathrm{~h}^{-1}$ year $^{-1}$ in the years 2011, 2012 and 2013, 
respectively when the annual rainfall was 673.8, 79.1 and $291.9 \mathrm{~mm}$, respectively. This clearly indicates that rainfall erosivity is linearly correlated to magnitude of the annual rainfall. The K-factor map indicates that the soil erodibility value is the lowest, i.e. 0.07 in the northern portion and the highest, i.e. 0.13 in the major part of the watershed. The L-factor is the highest $(0.4862)$ to moderate $(0.3823)$ in the northern and middle portions with the lowest value (0.3006) in the southern part. The low L-factor values are associated with high slope values in the southern portion of watershed. However, values of the S-factor are the highest $(>1)$ in the southern part where land slope is very high indicating relatively large vulnerability of this area to soil erosion. It is clear from Fig. 8 that the values of the $\mathrm{C}$-factor are the highest, i.e. 0.30 in the eastern part under agricultural lands. The southern part having open scrub land has moderate value of $\mathrm{C}$-factor (0.10). The P-factor value is the highest (0.85) for the cultivable wastelands in the north and northwest. The P-factor value is zero for the built-up lands, and 0.60 for the agricultural land.

\section{Annual Soil Erosion Potential}

The average annual soil erosion potential map of the watershed (Fig. 8) reveals that the soil loss in the watershed ranges from less than 5 to slightly more than 20 tonnes $\mathrm{ha}^{-1}$ year $^{-1}$. The soil erosion potential in the area is slight $\left(0-5 \mathrm{tha}^{-1}\right.$ year $\left.^{-1}\right)$, moderate (5$10 \mathrm{t} \mathrm{ha}^{-1}$ year $\left.^{-1}\right)$, high (10-20 $\mathrm{tha}^{-1}$ year $\left.^{-1}\right)$, and very high to severe (more than $20 \mathrm{t} \mathrm{ha}^{-1}$ year $^{-1}$ ) in 50, 41, 5 and $4 \%$ area, respectively.

\section{Studies on Desertification Assessment}

Desertification assessment, monitoring and control measure studies have remained the core activities and mandates of CAZRI since 1959. The process of assessment includes understanding the desert terrain, identification of key physical indicators and their interpretation through systematic mapping (using both satellite and field indicators). The first of this exercise to assess and map desertification in India was carried out at this institute in 1977 in connection with the first UN Conference on Desertification (UNCOD) at Nairobi, when the CAZRI scientists prepared a desertification map for arid western Rajasthan at 1:2 Million scale as per UN guidelines and nomenclatures. The map prepared by a team of experts from geomorphology, soils, hydrology, plant ecology and water resources at this institute was published in a A4 format in 1992 which was later updated and published at 1:1M scale in 2005. According to the above mapping, out of $20.875 \mathrm{~m}$ ha area mapped area, $19.175 \mathrm{~m}$ ha (92\% of the total mapped area) was degraded, and the rest was free from any degradation. While $33 \%$ area was slightly affected, $35 \%$ area was moderately affected and $24 \%$ severely. Wind erosion constituted the largest area ( $76 \%$ of the total mapped area; $26 \%$ slightly affected, $35 \%$ moderately and $15 \%$ severely). Water erosion was mapped in $15 \%$ area, while waterlogging and salinity was mapped in $6 \%$ area.

\section{Current Assessment of Degradation}

During 2003, as a part of India's commitment towards preparation of a regional DSM (Desertification Status Map) under the Thematic Programme Network-1 (TPN-1) of UNCCD (United Nations Conversion to Conbat Desertification), desertification maps were prepared at 1:1M scale, using data from the Advanced Wide Field Sensor (AWiFS) of Indian Remote Sensing Satellite, IRS-P6-Resourcesat. A national classification system was first developed through a pilot project in which SAC (Space Application Centre), CAZRI and few other institutions were involved. The team evolved a basic framework of classification and identified 12 land use/land cover categories, 13 degradation processes and 2 severity classes (high and low) for mapping. The mapping used two severity classes; "high" for severe and "low" for slight to moderate degradation, looking at the sensor limitations to distinction between slight and moderate degradation through visual interpretation.

The mapping revealed that $83.85 \%$ (176418 $\mathrm{km}^{2}$ ) area in western Rajasthan (total mapped area, $\left.210399 \mathrm{~km}^{2}\right)$ and $96.40 \%\left(72287 \mathrm{~km}^{2}\right)$ area in arid western Gujarat (total mapped area, $74984 \mathrm{~km}^{2}$ ) is affected by various degradation process. The database reveals $\sim 76 \%$ area of western Rajasthan is affected by wind erosion, encompassing all the major land uses, but mostly under croplands and dunes/sandy areas, while water erosion has affected $\sim 2 \%$ (mostly in croplands and scrublands), salinization $\sim 2 \%$ (mostly in croplands) and vegetation degradation $\sim 3 \%$ (especially in scrublands and forests). Mining activities 
Table 8: Highly intense rainfall storms at Kukma, Bhuj during 2007-2013 period

\begin{tabular}{|c|c|c|c|c|c|}
\hline S.No. & Year & Duration & Date & Rainfall (mm) & $\%$ of Annual Rainfall \\
\hline 1 & 2007 & Consecutive 2-days & $2^{\text {nd }}$ and $3^{\text {rd }}$ July & 200 & 59 \\
\hline 2 & & Consecutive 2-days & $9^{\text {th }}$ and $10^{\text {th }}$ August & 217.2 & \\
\hline 3 & 2008 & Single-day & $2^{\text {nd }}$ August & 49 & 45 \\
\hline 4 & & Consecutive 2-days & $14^{\text {th }}$ and $15^{\text {th }}$ September & 102 & \\
\hline 5 & 2009 & Single-day & $25^{\text {th }}$ July & 94 & 68 \\
\hline 6 & & Consecutive 2-days & $30^{\text {th }}$ and $31^{\text {st }}$ August & 260 & \\
\hline 7 & 2010 & Consecutive 4-days & $30^{\text {th }}$ and $31^{\text {st }} \mathrm{July}$, and $1^{\text {st }}$ and $2^{\text {nd }}$ August & 369 & 38 \\
\hline 8 & 2011 & Consecutive 2-days & $11^{\text {th }}$ and $12^{\text {th }}$ August & 156 & 46 \\
\hline 9 & & Single-day & $15^{\text {th }}$ August & 57 & \\
\hline 10 & & Consecutive 2-days & $5^{\text {th }}$ and $7^{\text {th }}$ September & 246 & \\
\hline 11 & 2013 & Consecutive 3 -days & $25^{\text {th }}, 26^{\text {th }}$ and $27^{\text {th }}$ September & 181.4 & 62 \\
\hline
\end{tabular}

\section{R-Factor}

(a) Year 2011

(b) Year 2012

(c) Year 2013

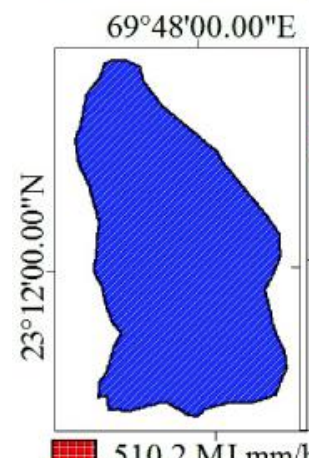

$69^{\circ} 48^{\prime} 00.00^{\prime \prime} \mathrm{E}$

$69^{\circ} 48^{\prime} 00.00^{\prime \prime} \mathrm{E}$

\section{K-Factor}

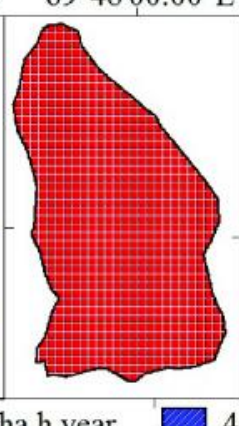

$2529.02 \mathrm{MJ} \mathrm{mm} / \mathrm{ha} h$ year

\section{L-Factor}

S-Factor

C-Factor $69^{\circ} 48^{\prime} 00.00 " \mathrm{E}$

\section{P-Factor} $69^{\circ} 48^{\prime} 00.00^{\prime \prime} \mathrm{E}$ $69^{\circ} 48^{\prime} 00.00^{\prime \prime} \mathrm{E}$
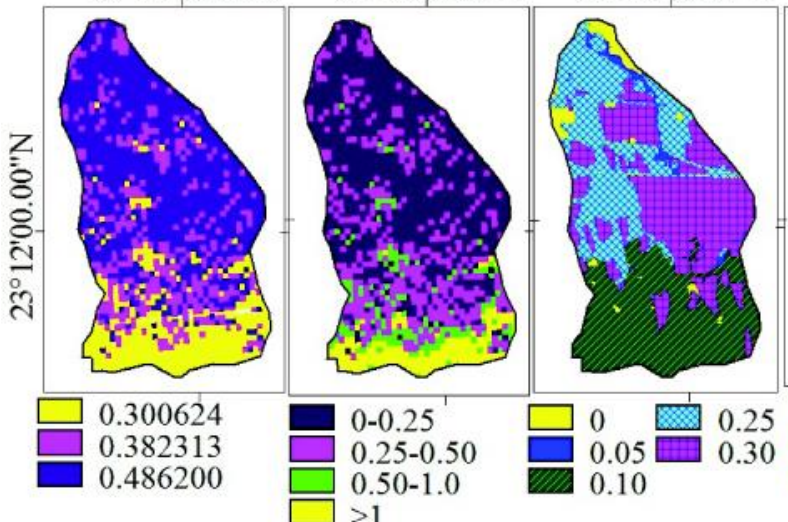

$69^{\circ} 48^{\prime} 00.00^{\prime \prime} \mathrm{E}$
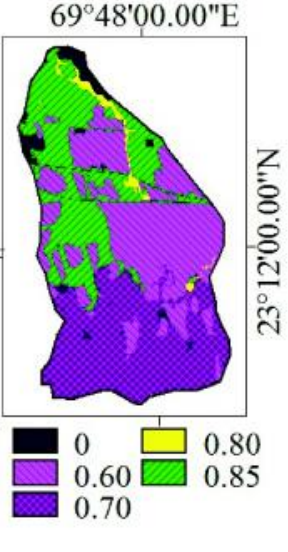

Mean Soil Erosion

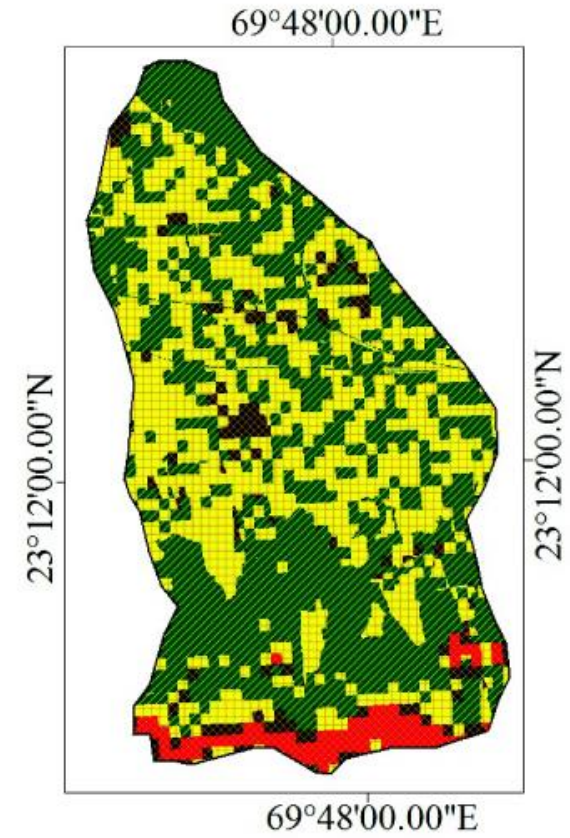

Soil Loss Classes

0-5 t/ha/year

5-10 t/ha/year

10-20 t/ha/year

$>20$ t/ha/year

Fig. 8: Maps of rainfall erosivity factor (R), soil erodibility factor (K), slope-length factor (L), slope-steepness factor (S), crop cover factor (C), management practice factor (P), and average annual soil loss of Kukma watershed 


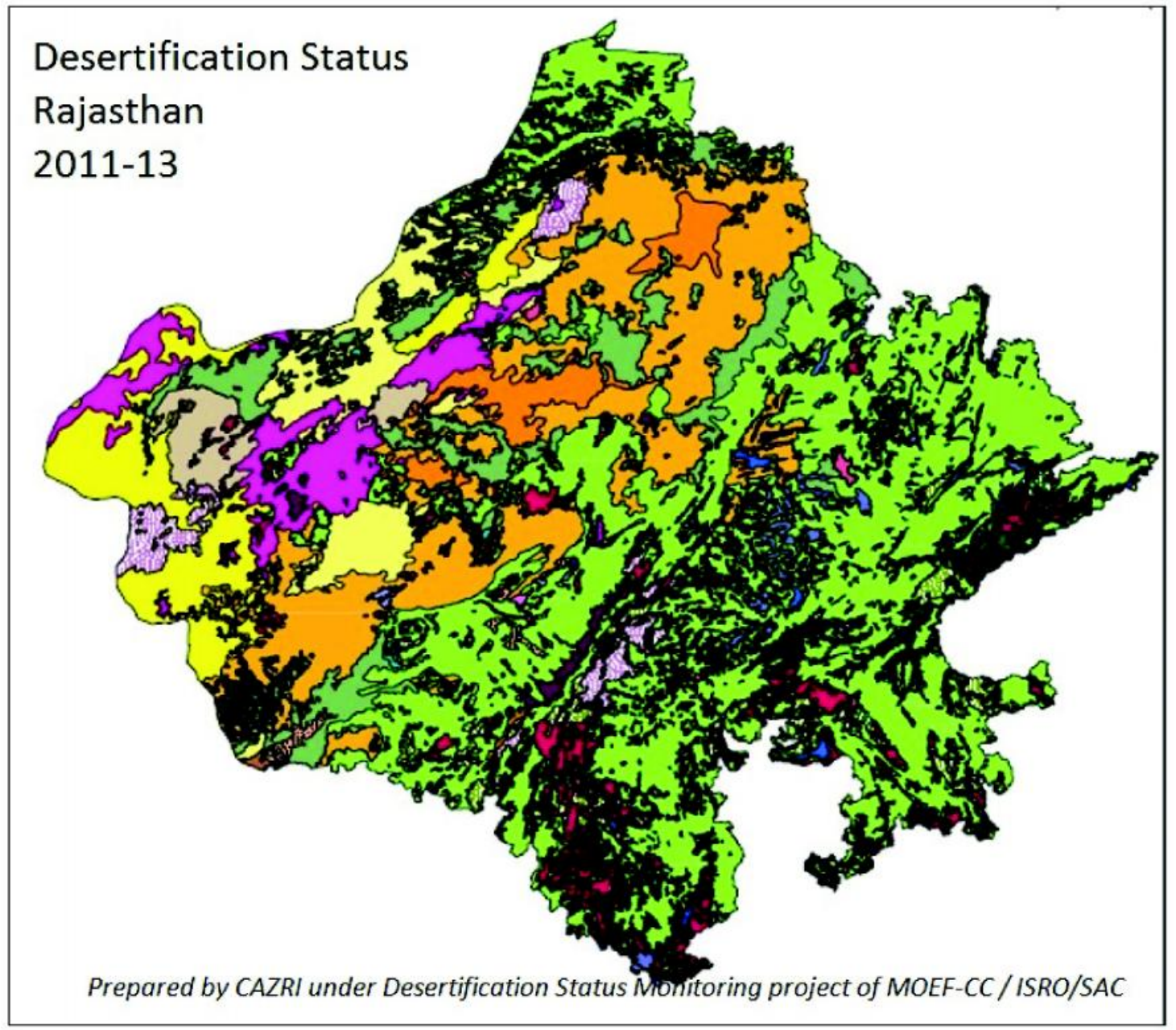

\begin{tabular}{|c|c|c|c|c|c|}
\hline $\begin{array}{l}\text { Wind Erosion } \\
\text { / Deposition }\end{array}$ & $\begin{array}{l}\text { Water } \\
\text { Erosion }\end{array}$ & $\begin{array}{l}\text { Salinityl } \\
\text { Alkalinity }\end{array}$ & $\begin{array}{l}\text { Water } \\
\text { Logging }\end{array}$ & $\begin{array}{l}\text { Vegetation } \\
\text { Degradation }\end{array}$ & $\begin{array}{l}\text { Barren } \\
\text { / Rocky }\end{array}$ \\
\hline$\square$ De1 & $\square$ Dw1 & F圈 Ds1 & $\square$ DI1 & Fv1 & $\square B$ \\
\hline De2 & | $|w|$ & Ds2 & | |l1 |1 | - | & 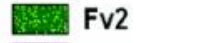 & R \\
\hline le1 & IW2 & Is1 & El1 & Sv1 & \\
\hline le2 & $\square$ Fw1 & Is2 & E12 & Sv2 & Iviming \\
\hline Se1 & $\mathrm{FW} 2$ & Ss1 & & & $\mathrm{Fm} 2$ \\
\hline $\mathrm{Se} 2$ & SW1 & Ss2 & & & Tm1 \\
\hline Be1 & Sw2 & Bs1 & & & \\
\hline Ee1 & Bw1 & Bs2 & & & \\
\hline $\mathrm{Ee} 2$ & Ew1 & & & & \\
\hline
\end{tabular}

Desertification Status Map of Rajasthan (Based on interpretation of IRS-AWiFS data of 2011-13

Land use / Land cover units D : Agriculture, un-irrigated I: Agriculture, irrigated $\mathrm{F}$ : Forest

G : Grazing land

$S$ : Land with scrub

B/R : Barren / Rocky area

E : Sandy / Dunes

$\mathrm{T}$ : Built up / Mining

Degradation type and Severity

Wind erosion $=\mathrm{e}$

Water erosion $=\mathrm{w}$

Salinity/alkalinity $=\mathrm{s}$

Waterlogging $=1$

Vegetation degradation $=\mathrm{v}$

Mining $=\mathrm{m}$

1 : Slight-Moderate type

2: Severe type

Fig. 9: Desertification Status Map of Rajasthan 
have spoiled so far only $0.10 \%$ area, and degraded rocky areas cover $1 \%$ area. About $18 \%$ area is severely degraded and $66 \%$ slight to moderately, while $16 \%$ area is not affected by degradation. In arid Gujarat, water erosion is the dominant process, affecting $43 \%$ of the total area (mostly in croplands), followed by salinity (38\%), while vegetation degradation (10\%) and wind erosion $(5 \%)$ cover some areas. About $44 \%$ of area is severely affected, and $53 \%$ slight to moderately, and 3\% area is not affected.

Very recently, the institute also contributed to Desertification Status Monitoring of Rajasthan for a MoEF\& CC, Government of India sponsored National Map at 1:1 Million scale, carried out by SAC/ISRO, Ahmedabad. The mapping and monitoring was carried out using IRS AWiFS satellite data of 2003-05 and 2011-13. The database and maps have been published recently in June 2016 in the form of "Desertification and Land degradation Atlas of India" (Reference of this is available at http://vedas.sac.gov.in/vedas/ downloads/atlas/DSM/Desertification_Atlas _2016_SAC_ISRO.pdf).

The result indicated that as per 2011-13 data, $62.90 \%$ area of the total geographical area of Rajasthan (34223900 ha) is affected by various process of desertification. This indicates an overall decrease of degraded area by 99092 ha (from 21625604 ha or $63.13 \%$ in $2003-05$ to 21526512 ha $(62.90 \%)$ in 2011-13. Area affected by wind erosion / deposition has been mapped in maximum area; 15332053 ha (44.80\%) in 2003-05 and 15197873 ha $(44.41 \%)$ in 2011-13 indicating a decrease by 0.39 $\%$ area. Water erosion has affected about 2116315 ha $(6.97 \%)$ as per $2011-13$ data indicating increase by $0.8 \%$ area in comparison to 2003-05. Vegetation degradation has been assessed in 2606222 ha (7.61 $\%$ area) in 2011-13, an increase by $0.03 \%$ area over the year, 2003-05 Area under Salinity/alkalinity has decreased in 1898 ha.

Several field based experiments have been carried out to quantify soil erosion and related nutrient loss in western Rajasthan. It was found that strip cropping of legumes with pasture grass (1:3) reduced the soil loss to $20.5 \mathrm{t} \mathrm{ha}^{-1}$ in comparison to the bare field after sole cropping $\left(48 \mathrm{t} \mathrm{ha}^{-1}\right)$. Under such condition, the equivalent loss of soil organic carbon and total nitrogen was 44 to $48 \mathrm{~kg} \mathrm{ha}^{-1}$ and 3.0 to 3.2 $\mathrm{kg} \mathrm{ha}^{-1}$ respectively. The institute carried out some exercises on soil loss due to dust storms and found that due to dust sand storm, the soils get depleted of the available silt and clay and other nutrients. Field based measurements at Jaisalmer and Chandan found higher concentration of PM10 and PM2.5 at both places (20\% and $15.5 \%$ respectively). The PM2.5 was higher in Chandan than in Jaisalmer. It was observed that at Chandan, dense occurrences of grass clumps of Lasiurus sindicus and Panicum turgidum as well as higher percentage of silt and clay in the soil might have reduced the emission of such particles. It was also found that finer soils of western part of Thar Desert may be the major sources of atmospheric dust occurring in eastern Rajasthan and adjoining parts of Uttar Pradesh and Madhya Pradesh. Satellite based interpretation also suggested similar pattern and distribution of aerosol in those region.

\section{Way Forward}

CAZRI celebrated its 50 years of establishment in 2009. It remembered its committments to research on arid land management. The institute has assessed situations of scarce and erratic rainfall, extremes of climate, coarse textured soils, depleting groundwater and other natural resources that is expected to pose serious challenges to arid production systems. The scientists are working for the development of newer agro technologies in several areas with overall objective to enhance the resilience of farming system to climatic stresses and to increase the income of farmers. Therefore, coming decades will be very crucial in view of the changing demographic and climatic scenario. Keeping this in mind, several new programmes have been initiated.

A new project on "wind erosion and soil loss in the region and its impact on agricultural production" is in operation focusing quantifying the relationship through field based measurements. New projects on efficient use of solar and wind power in arid regions for agriculture and rural livelihood have been in operation for developing agrivoltaic land use system, solar PV pump based micro-irrigation system for efficient use of water in dryland agriculture, dual purpose wind barrier to control wind erosion as well as to harness wind energy etc. Initiatives have also been taken to study wind erosion process through wind tunnel simulations, efficient use of water through watershed approach, etc. 


\section{Publications}

Gaur M K and Moharana P C (2014) Environment, People and Development: Experiences from Desert Ecosystems. New India Publishing Agency, New Delhi, $348 \mathrm{p}$

Goyal R K, Khan M A, Bhati T K, Pandey C B and Roy M M (2013) Watershed Management for Development of Hot Arid Zone of India.CAZRI, Jodhpur, India, $46 \mathrm{p}$

Goyal R K, Saxena A, Moharana P C and Pandey C B (2013) Crop water demand under climate change scenarios for western Rajasthan Annals of Arid Zone 52 89-94

Kumar M and Sharma B K (2010) Micronutrients status of soils irrigated with high residual sodium carbonate water Annals of Arid Zone 49 137-140

Kumar M, Singh S K, Raina P and Sharma B K (2011) Available major and micronutrients in arid soils of Churu district of western Rajasthan Journal of the Indian Society of Soil Science 59 188-192

Kumar S and Roy M M (2012) Desert Botanical Garden (A Lead Garden in the Indian Desert). CAZRI, Jodhpur, $64 \mathrm{p}$

Machiwal D and Jha M K (2012) Hydrologic Time Series Analysis: Theory and Practice. Capital Publishing Company, New Delhi, India and Springer, Germany, $303 \mathrm{p}$

Machiwal D, Jha M K and Mal B C (2011) Assessment of groundwater potential in a semi-arid region of India using remote sensing, GIS and MCDM techniques Water Resources Management 25 1359-1386

Machiwal D, Jha M K and Mal B C (2011) GIS-based assessment and characterization of groundwater quality in a hard-rock hilly terrain of western India Environmental Monitoring and Assessment 174 645-663

Machiwal D, Nimawat J V and Samar K K (2011) Evaluating efficacy of groundwater level monitoring network by graphical and multivariate statistical techniques Journal of Agricultural Engineering, ISAE 48 36-43

Mertia R S, Santra P, Kandpal B K and Prasad R (2010) Massheight profile and total mass transport of wind eroded aeolian sediments from rangelands of Indian Thar Desert Aeolian Research 2 135-142

Moharana P C (2011) Geomorphic assessment and mapping of gullied landscapes in the eastern margin of Thar Desert using GIS and remote sensing Indian Cartographer $\mathbf{3 1}$ 176-181

Moharana P C (2012) Types, distribution and morphology of aeolian bedforms in canal-irrigated region of arid western Rajasthan Journal of Indian Geomorphology 1 1-7
Moharana P C and Kar A (2010) Quantitative measurement of arid fluvial processes: Results from an upland catchment in Thar Desert Journal of the Geological Society of India 76 86-92

Moharana P C, Soni S and Bhatt R K (2013) NDVI based assessment of desertification in arid part of Rajasthan in reference to regional climate variability Indian Cartographer 33 319-325

Painuli D K, Goyal R K, Singh B, Kalia R K and Roy M M (2014) Impact Evaluation of Watershed Programs in Jaisalmer District of Rajasthan. ICAR-Central Arid Zone Research Institute, Jodhpur, Rajasthan, India, 26 p.

Raja P, Bhattacharya B K, Singh N, Sinha N K, Singh J P, Pandey C B, Parihar J S and Roy M M (2012) Surface energy balance and its closure in arid grassland ecosystems: A case study over Thar Desert Journal of Agrometeorology 194-99

Raja P, Bhattacharya B K, Singh N, Sinha N K, Singh J P, Parihar J S and Roy M M (2013) Seasonal radiation and energy fluxes in a desert grassland ecosystem E Journal of Applied Forest Ecology 2 45-52

Rao A S and Poonia S (2011) Climate change impact on crop water requirements in arid Rajasthan Journal of Agrometeorology 13 17-24

Rao A S and Roy M M (2012) Weather Variability and Crop Production in Arid Rajasthan. Central Arid Zone Research Institute, Jodhpur, $70 \mathrm{p}$

Santra P, Das B S and Chakravarty D (2010) Delineation of hydrologically similar units in a watershed based on fuzzy classification of soil hydraulic properties Hydrological Processes 25 64-79

Santra P, Das B S and Chakravarty D (2012) Spatial prediction of soil properties in a watershed scale through maximum likelihood approach Environmental Earth Science 65 20512061

Santra P, Mertia R S and Kushawa H L (2010) A new wind erosion sampler for monitoring dust storm events in the Indian Thar Desert Current Science 99 1061-1067

Santra P, Mertia R S, Kumawat R N, Sinha N K and Mahla H R (2013) Loss of soil carbon and nitrogen through wind erosion in the Indian Thar desert Journal of Agricultural Physics 13 13-21

Santra P, Singh R, Sarathjith M C, Panwar N R, Varghese P and Das B S (2015) Reflectance spectroscopic approach for estimation of soil properties in hot arid western Rajasthan, India Environmental Earth Science 74 4233-4245 
Singh D V, Purohit R S, Mertia R S, Laxminarayan, Poonia S and

Kar A (2011) Agrometeorological Data Handbook of Jodhpur (1971-2010). Central Arid Zone Research Institute, Jodhpur, $110 \mathrm{p}$
Singh P K, Machiwal D and Roy M K (2011) Modelling daily runoff and probabilistic estimation of design maximum daily runoff from selected watersheds of Udaipur, Rajasthan Indian Journal of Soil Conservation 39 176182. 